\title{
Authigenic carbonate precipitation at the end-Guadalupian (Middle Permian) in China: Implications for the carbon cycle in ancient anoxic oceans
}

Masafumi Saitoh ${ }^{1,2,3,8^{*}}$, Yuichiro Ueno ${ }^{1,2,3}$, Yukio Isozaki ${ }^{4}$, Takazo Shibuya ${ }^{1}$, Jianxin Yao ${ }^{5}$, Zhansheng $\mathrm{Ji}^{5}$, Katsumi Shozugawa ${ }^{6}$, Motoyuki Matsuo ${ }^{6}$ and Naohiro Yoshida ${ }^{3,7}$

\begin{abstract}
Carbonate precipitation is a major process in the global carbon cycle. It was recently proposed that authigenic carbonate (carbonate precipitated in situ at the sediment-water interface and/or within the sediment) played a major role in the carbon cycle throughout Earth's history. The carbon isotopic composition of authigenic carbonates in ancient oceans have been assumed to be significantly lower than that of dissolved inorganic carbon (DIC) in seawater, as is observed in the modern oceans. However, the $\delta^{13} C_{\text {carb }}$ values of authigenic carbonates in the past has not been analyzed in detail. Here, we report authigenic carbonates in the uppermost Guadalupian (Middle Permian) rocks at Chaotian, Sichuan, South China. Monocrystalline calcite crystals $<20 \mathrm{~mm}$ long are common in the black mudstone/chert sequence that was deposited on a relatively deep anoxic slope/basin along the continental margin. Textures of the crystals indicate in situ precipitation on the seafloor and/or within the sediments. The calcite precipitation corresponds stratigraphically with denitrification and sulfate reduction in the anoxic deep-water mass, as indicated by previously reported nitrogen and sulfur isotope records, respectively. Relatively high $\delta^{13} C_{\text {carb }}$ values of the authigenic carbonates (largely $-1 \%$ ) compared with those of organic matter in the rocks (ca. $-26 \%$ ) suggest that the main carbon source of the carbonates was DIC in the water column. The calcite crystals precipitated in an open system with respect to carbonate, possibly near the sediment-water interface rather than deep within the sediments. The $\delta^{13} C_{\text {carb }}$ values of the carbonates were close to the $\delta^{13} C_{\text {DIC }}$ value of seawater due to mixing of ${ }^{13} \mathrm{C}$-depleted remineralized organic carbon (that was released into the water column by the water-mass anaerobic respiration) with the large $\mathrm{DIC}$ pool in the oceans. Our results imply that $\delta^{13} \mathrm{C}_{\text {carb }}$ values of authigenic carbonates in the anoxic oceans might have been systematically different from the values in the oxic oceans in Earth's history, controlled by the depth of the redoxcline in the water column and sediments. If our model is correct, authigenic carbonates with relatively high $\delta^{13} C_{\text {carb }}$ values in the ancient anoxic oceans may have had a less substantial influence on the bulk $\delta^{13} \mathrm{C}_{\text {carb }}$ values in geologic records than has been previously suggested.
\end{abstract}

Keywords: Middle Permian, South China, Anoxic deep-water, Authigenic carbonate, Carbon isotopic composition, Oxic/anoxic oceans, Redoxcline depth, Water-mass anaerobic respiration

\footnotetext{
* Correspondence: saitoh.m.ab@jamstec.go.jp

'Laboratory of Ocean-Earth Life Evolution Research (OELE), Japan Agency for

Marine-Earth Science and Technology (JAMSTEC), 2-15 Natsushima-cho,

Yokosuka 237-0061, Japan

${ }^{2}$ Department of Earth and Planetary Sciences, Tokyo Institute of Technology,

2-12-1 Ookayama, Meguro, Tokyo 152-8551, Japan

Full list of author information is available at the end of the article
} 


\section{Background}

Carbonate precipitation is a major process in the global carbon cycle and is thought to have been closely related to climate changes throughout Earth's history (e.g., Walker et al. 1981; Kasting 1993; Ridgwell and Zeebe 2005). The precipitation of carbonate has also been an important factor in the carbon isotope mass balance in both ancient and modern oceans. In a general model of the global carbon cycle, the input of carbon to the oceans is balanced by its output via two major pathways, normal marine carbonate precipitation and organic carbon burial (Shackleton and Hall 1984). Biotic and/or abiotic carbonate precipitation of dissolved inorganic carbon (DIC) in the oceans exhibits little carbon isotope fractionation, whereas organic matter generated by biological carbon fixation is depleted in ${ }^{13} \mathrm{C}$ relative to seawater DIC. The carbon isotopic composition of seawater DIC $\left(\delta^{13} C_{\text {DIC }}\right)$, and consequently that of the carbonate mineral $\left(\delta^{13} \mathrm{C}_{\text {carb }}\right)$, is interpreted to represent the partitioning of carbon between the two major sinks. On the basis of a compilation of $\delta^{13} C_{\text {carb }}$ values in geologic records from numerous previous studies, carbonate precipitation is suggested to have accounted for up to $80 \%$ of total carbon removal from the ocean during most of Earth's history (Hayes et al. 1999; Shields and Veizer 2002).

Recently, Schrag et al. (2013) introduced a new component into a model of the global carbon cycle in the past. They proposed that authigenic carbonate, inorganically precipitated in situ at the sediment-water interface and/ or within the sediments associated with anaerobic respiration (sulfate and iron reduction), has played a major role in Earth's history. They also suggested that the global authigenic carbonate sink represented a major component of the carbon isotope mass balance in the past, particularly in the anoxic oceans in the Precambrian and Paleozoic, although this sink may also be significant in the modern oxic oceans (Sun and Turchyn 2014). According to the model of Schrag et al. (2013), secular changes in the size of the global sink of ${ }^{13} \mathrm{C}$-depleted authigenic carbonate could change the $\delta^{13} \mathrm{C}_{\mathrm{DIC}}$ value in the oceans without large fluctuations in atmospheric $\mathrm{O}_{2}$ and $\mathrm{CO}_{2}$ levels. They assumed that the $\delta^{13} \mathrm{C}_{\text {carb }}$ values of authigenic carbonate have been substantially lower than the $\delta^{13} C_{\text {DIC }}$ value of seawater in the past, as observed in the modern oceans. However, the $\delta^{13} \mathrm{C}_{\text {carb }}$ values of authigenic carbonate throughout Earth's history have yet to be studied in detail.

We analyzed the Guadalupian-Lopingian (MiddleUpper Permian) rocks in the Chaotian section in northern Sichuan, South China, to examine the environmental changes related to the end-Guadalupian extinction (Fig. 1; Isozaki et al. 2004). In our previous studies, we identified evidence for anoxia and for water-mass denitrification and sulfate reduction on the relatively deep slope/basin along the continental margin, prior to the extinction (Fig. 1c; Isozaki et al. 2008; Saitoh et al. 2013a, 2013b, 2014a). Here, we report on the occurrence of anomalous carbonate crystals in a characteristic interval of deep-water facies in the uppermost Guadalupian at Chaotian. To clarify the origin of these crystals, we describe the textures and analyze the inorganic carbon and oxygen isotopic compositions of the carbonates. We classify the Chaotian carbonates as authigenic carbonate and discuss their generation mechanisms. Moreover, based on our results, we argue the influence of authigenic carbonate on the bulk $\delta^{13} \mathrm{C}_{\mathrm{carb}}$ values in geologic records, considering the systematic difference in $\delta^{13} C_{\text {carb }}$ values between authigenic carbonates in the oxic and anoxic oceans throughout Earth's history.

\section{Methods}

The Chaotian section is located nearly $20 \mathrm{~km}$ north of the city of Guangyuan in northern Sichuan, South China $\left(32^{\circ} 37^{\prime} \mathrm{N}, 105^{\circ} 51^{\prime} \mathrm{E}\right.$; Fig. 1a; Isozaki et al. 2004). At Chaotian, Middle Permian to lowermost Triassic carbonates are continuously exposed along the bank of the Jialingjiang River in a narrow gorge called Mingyuexia (Fig. 1c). We mapped the eastern bank of the gorge, particularly focusing on the $\sim 30 \mathrm{~m}$ thick Middle-Upper Permian rocks. Fresh rock samples were collected by field mapping and by deep drilling to a depth of $>150 \mathrm{~m}$. We described the textures of the rocks based on petrographic observations of polished slabs and thin sections. To determine the mineral compositions of the carbonate samples, X-ray diffraction (XRD) analyses were conducted on a new D8 Advance (Bruker) diffractometer equipped with a graphite monochromator at The University of Tokyo and operated at $40 \mathrm{kV}$ and $40 \mathrm{~mA}$ using $\mathrm{Cu}-\mathrm{K} \alpha$ radiation. Selected samples were powdered and mounted on plastic holders $(\varnothing=25 \mathrm{~mm}$, depth $=1$ $\mathrm{mm})$. The oriented samples were scanned over an interval of $5^{\circ}-60^{\circ}(2 \theta)$ at a scanning speed of $1.375^{\circ} / \mathrm{min}$ for every $0.03^{\circ}(2 \theta)$ step. The divergence, scattering, and receiving slits were $0.6,0.6$, and $0.10 \mathrm{~mm}$, respectively.

In addition to the lithofacies description and XRD analysis, the inorganic carbon and oxygen isotopic compositions of carbonate samples were analyzed at Tokyo Institute of Technology. Powdered samples were reacted with $>100 \%$ phosphoric acid at $80{ }^{\circ} \mathrm{C}$ for $>12 \mathrm{~h}$ using a Thermoquest GasBench II. The extracted $\mathrm{CO}_{2}$ was separated in a chromatography line with a helium flow, and the carbon and oxygen isotope ratios were measured with a DELTA Plus XL mass spectrometer, following a modified version of the method in Revesz and Landwehr (2002). The carbonate carbon and oxygen isotope compositions $\left(\delta^{13} \mathrm{C}_{\text {carb }}\right.$ and $\left.\delta^{18} \mathrm{O}_{\text {carb }}\right)$ are reported in per mil notation relative to Vienna Peedee Belemnite (\%o VPDB). The analytical reproducibility of the $\delta^{13} C_{\text {carb }}$ and $\delta^{18} \mathrm{O}_{\text {carb }}$ values, determined by replicate analyses of the 


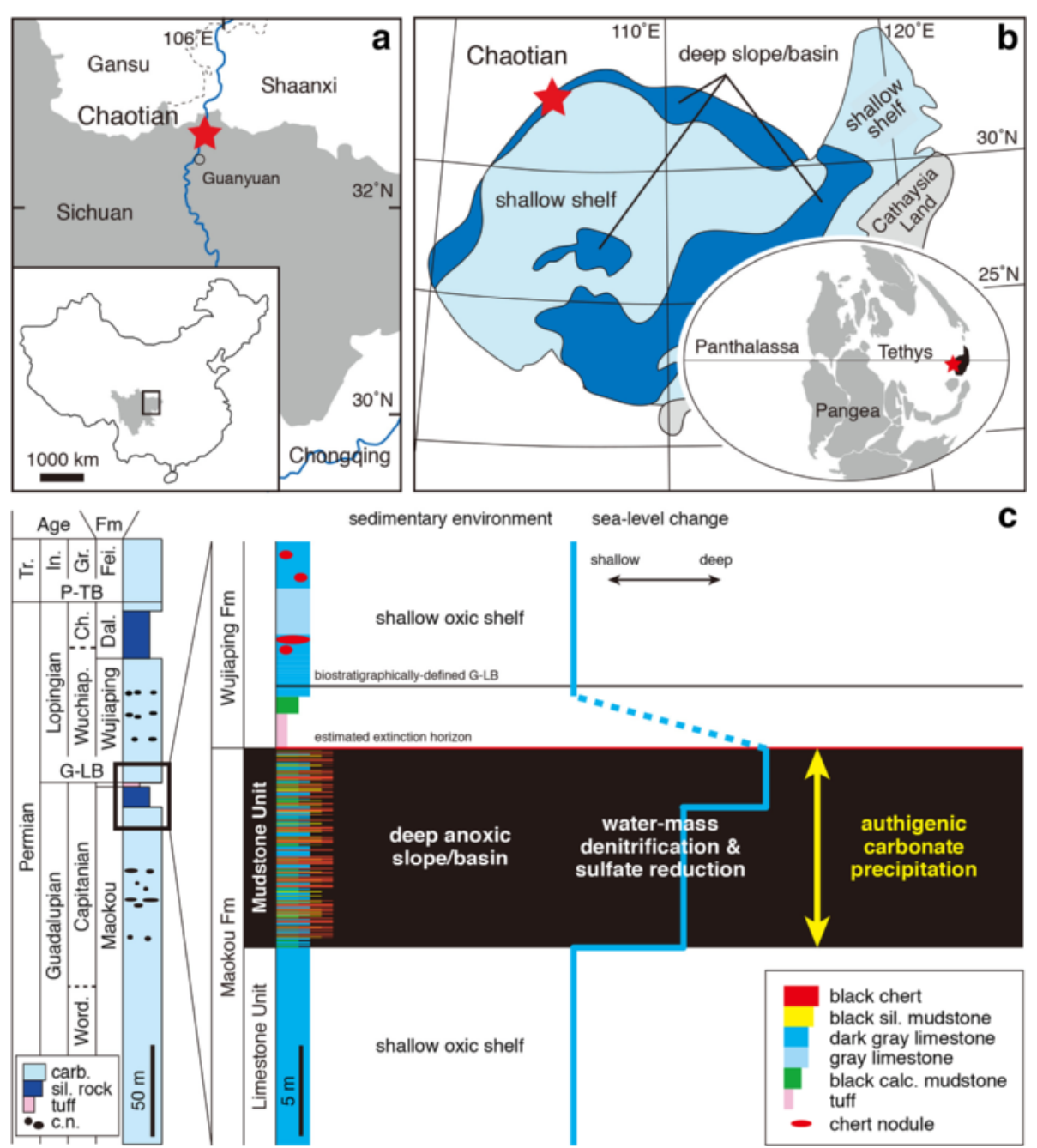

Fig. 1 Stratigraphy of the Chaotian section. a Location of the Chaotian section. b Paleogeography of South China in the Capitanian (Late Guadalupian) modified from Wang and Jin (2000). The global paleogeography is shown in the inset. South China is shown in black, and a red star represents the location of Chaotian. c Stratigraphy across the Guadalupian-Lopingian (Middle-Upper Permian) boundary (G-LB) at Chaotian. The sedimentary environments and sea-level changes are modified from Saitoh et al. (2013a). carb. carbonates, calc. calcareous, sil. siliceous, c.n. chert nodule, Word. Wordian, Wuchiap. Wuchiapingian, Ch. Changhsingian, Dal. Dalong, Tr. Triassic, In. Induan, Gr. Griesbachian, Fei. Feixianguan, P-TB Permian-Triassic boundary

laboratory standard, were better than 0.3 and $0.4 \%$, respectively.

We conducted simple thermodynamic calculations to examine changes in chemical compositions (e.g., the saturation state of carbonate) in hypothetical Permian seawater associated with anaerobic respiration. We used a one-box model with the chemical compositions of the initial seawater based on values taken from previous studies (Tables 1 and 2). We assumed that the total $\mathrm{Na}$ concentration $\left(\sum \mathrm{Na}=\mathrm{Na}^{+}+\mathrm{NaCO}_{3}^{-}+\mathrm{NaCl}(\mathrm{aq})+\right.$ $\left.\mathrm{NaHCO}_{3}(\mathrm{aq})+\mathrm{NaOH}(\mathrm{aq})\right)$ and the total $\mathrm{Cl}$ concentration $\left(\Sigma \mathrm{Cl}=\mathrm{Cl}^{-}+\mathrm{CaCl}^{+}+\mathrm{CaCl}_{2}\right.$ (aq) $+\mathrm{NaCl}(\mathrm{aq})+$ $\mathrm{HCl}(\mathrm{aq})$ ) in the initial seawater were $500 \mathrm{mmol} / \mathrm{L}$. We also assumed that the total $\mathrm{S}$ concentration $(\Sigma \mathrm{S}=$ $\mathrm{SO}_{4}{ }^{2-}+\mathrm{HSO}_{4}{ }^{-}+\mathrm{CaSO}_{4}$ (aq) $+\mathrm{H}_{2} \mathrm{~S}+\mathrm{HS}^{-}+\mathrm{S}_{2}^{-}$) in the initial seawater was $20 \mathrm{mmol} / \mathrm{L}$ according to a recent reconstruction of the secular changes in seawater sulfate concentrations in the Phanerozoic based on sulfur isotope records (Algeo et al. 2015). The total Ca concentration $\left(\Sigma \mathrm{Ca}=\mathrm{Ca}^{2+}+\mathrm{CaCO}_{3}\right.$ (aq) $+\mathrm{CaCl}^{+}+\mathrm{CaCl}_{2}$ (aq) + $\mathrm{CaHCO}_{3}{ }^{+}+\mathrm{CaSO}_{4}$ (aq)) at the initial condition was assumed to be $15 \mathrm{mmol} / \mathrm{L}$ based on secular variations in the Phanerozoic reconstructed by Stanley and Hardie (1998). We assumed that the total DIC concentration $\left(\Sigma \mathrm{CO}_{2}=\mathrm{CO}_{2}(\mathrm{aq})+\mathrm{HCO}_{3}^{-}+\mathrm{CO}_{3}^{2-}+\mathrm{CaCO}_{3}(\mathrm{aq})+\right.$ $\left.\mathrm{CaHCO}_{3}{ }^{+}+\mathrm{NaCO}_{3}{ }^{-}+\mathrm{NaHCO}_{3}(\mathrm{aq})\right)$ in the initial seawater was $2 \mathrm{mmol} / \mathrm{kg}$ according to an estimation by Arvidson et al. (2014). Although nitrate concentrations in the Permian oceans are poorly constrained, we assumed that the total $\mathrm{N}$ concentration $\left(\sum \mathrm{N}=\mathrm{NO}_{3}^{-}+\mathrm{HNO}_{3}(\mathrm{aq})+\right.$ 
Table 1 Model input parameters

\begin{tabular}{lrll}
\hline & Value & Units & References \\
\hline$\Sigma \mathrm{Na}^{\mathrm{a}}$ & 500 & $\mathrm{mmol} / \mathrm{L}$ & \\
$\Sigma \mathrm{Cl}$ & 500 & $\mathrm{mmol} / \mathrm{L}$ & \\
$\Sigma \mathrm{S}$ & 20 & $\mathrm{mmol} / \mathrm{L}$ & Algeo et al. (2015) \\
$\Sigma \mathrm{Ca}$ & 15 & $\mathrm{mmol} / \mathrm{L}$ & Stanley and Hardie (1998) \\
$\Sigma \mathrm{CO}_{2}{ }^{\mathrm{b}}$ & 2 & $\mathrm{mmol} / \mathrm{kg}$ & Arvidson et al. (2014) \\
$\Sigma \mathrm{N}^{\mathrm{C}}$ & 15 & $\mu \mathrm{mol} / \mathrm{L}$ & Lam et al. (2009) \\
$\mathrm{pH}$ & 7.8 & & Ridgwell (2005) \\
$\mathrm{Temperature}^{13}$ & 15 & ${ }^{\circ} \mathrm{C}$ & \\
$\delta^{13} \mathrm{C}_{\mathrm{DIC}}$ & +2 & $\%$ & \\
$\delta^{13} \mathrm{C}_{\text {org }}$ & -26 & $\%$ & \\
\hline
\end{tabular}

${ }^{a} \mathrm{Na}=\mathrm{Na}^{+}+\mathrm{NaCO}^{-}+\mathrm{NaCl}(\mathrm{aq})+\mathrm{NaHCO} 3(\mathrm{aq})+\mathrm{NaOH}(\mathrm{aq})$

The total elemental concentrations of the other elements are calculated in a similar way to $\Sigma \mathrm{Na}$ (see the "Methods" section and Table 3)

${ }^{\mathrm{b}}$ Total dissolved inorganic carbon (DIC)

'The value at the estimated water depth of the sedimentary environment (>150 $\mathrm{m}$ deep)

$\mathrm{N}_{2}(\mathrm{aq})$ ) in the initial seawater was $15 \mu \mathrm{mol} / \mathrm{L}$ based on the vertical $\mathrm{NO}_{3}^{-}$profile in the modern oceans (Lam et al. 2009) and on the estimated water depth of the sedimentary environment of the Mudstone Unit at Chaotian (>150 m deep) (Saitoh et al. 2013a). The pH of the initial seawater was assumed to be 7.8 on the basis of the model results by Ridgwell (2005). The temperature of the seawater was assumed to be $15{ }^{\circ} \mathrm{C}$. The $\delta^{13} \mathrm{C}_{\mathrm{DIC}}$ value of the initial seawater was assumed to be $+2 \%$ based on the previously reported $\delta^{13} C_{\text {carb }}$ records in the Mudstone Unit (Saitoh et al. 2013b). Model input parameters are listed in Table 1 , and the calculated chemical composition of the initial seawater is listed in Table 2 . We calculated the saturation index of calcite $(\Omega)$ as follows:

Table 2 Chemical compositions of the initial seawater $\left(S W_{i}\right)$ for the thermodynamic calculations

\begin{tabular}{llrl}
\hline & & Value & Units \\
\hline Aqueous species & $\mathrm{Na}^{+}$ & 495.0 & $\mathrm{mmol} / \mathrm{L}$ \\
& $\mathrm{Cl}^{-}$ & 483.1 & $\mathrm{mmol} / \mathrm{L}$ \\
& $\mathrm{SO}_{4}{ }^{2-}$ & 18.6 & $\mathrm{mmol} / \mathrm{L}$ \\
& $\mathrm{Ca}^{2+}$ & 13.1 & $\mathrm{mmol} / \mathrm{L}$ \\
& $\mathrm{DIC}$ & 2.0 & $\mathrm{mmol} / \mathrm{L}$ \\
& & 32.09 & $\mathrm{~g} / \mathrm{kg}$ \\
Salinity & & 1.03 & $\mathrm{~g} / \mathrm{cm}^{3}$ \\
Density & & 0.55 & \\
lonic strength & & 1.96 & $\mathrm{meq} / \mathrm{L}$ \\
Carbonate alkalinity & & 1.97 & \\
Calcite saturation index $(\Omega)$ & & 15 & ${ }^{\circ} \mathrm{C}$ \\
Temperature & & 7.8 & \\
pH & & 2.0 & $\%$ \\
$\delta^{13} C_{\text {DIC }}$ & & \\
\hline
\end{tabular}

$$
\Omega=\left(\gamma \mathrm{Ca}^{2+} \cdot \gamma \mathrm{CO}_{3}^{2-}\right) / K_{\mathrm{sp}}
$$

where $\gamma \mathrm{Ca}^{2+}$ and $\gamma_{\mathrm{CO}_{3}}{ }^{2-}$ are the activities of $\mathrm{Ca}^{2+}$ and $\mathrm{CO}_{3}{ }^{2-}$ in seawater, respectively, and $K_{\mathrm{sp}}$ is the solubility constant for calcite. The net reaction formulas for denitrification and sulfate reduction can be written as

$$
\begin{aligned}
& \mathrm{NO}_{3}^{-}+5 / 4\left(\mathrm{CH}_{2} \mathrm{O}\right)+\mathrm{H}^{+} \rightarrow 1 / 2 \mathrm{~N}_{2}+5 / 4 \mathrm{CO}_{2} \\
& \quad+7 / 4 \mathrm{H}_{2} \mathrm{O} \\
& \mathrm{SO}_{4}^{2-}+2\left(\mathrm{CH}_{2} \mathrm{O}\right)+2 \mathrm{H}^{+} \rightarrow \mathrm{H}_{2} \mathrm{~S}+2 \mathrm{CO}_{2} \\
& \quad+2 \mathrm{H}_{2} \mathrm{O}
\end{aligned}
$$

The composition of the seawater is modified as these reactions proceed, which were calculated using the REACT module in the computer code Geochemist's Workbench (Bethke 2008). The reaction path mimics the incremental addition of organic matter (as the addition of $\mathrm{C}$ and $\mathrm{H}_{2} \mathrm{O}$ because of the absence of thermodynamic data for $\mathrm{CH}_{2} \mathrm{O}$ ) into the seawater, in which the respiration reaction and the resulting compositional modification of the seawater is reevaluated at each step based on the reactions listed in Table 3 . Minerals (e.g., carbonate and sulfide) were not allowed

Table 3 Reaction formulas for the thermodynamic calculations in association with sulfate reduction

$$
\begin{aligned}
& \text { Aqueous species } \\
& \mathrm{CO}_{2}(\mathrm{aq})+\mathrm{H}_{2} \mathrm{O}=\mathrm{HCO}_{3}^{-}+\mathrm{H}^{+} \\
& \mathrm{CO}_{3}{ }^{2-}+\mathrm{H}^{+}=\mathrm{HCO}_{3}^{-} \\
& \mathrm{CaCO}_{3}(\mathrm{aq})+\mathrm{H}^{+}=\mathrm{HCO}_{3}^{-}+\mathrm{Ca}^{2+} \\
& \mathrm{CaCl}^{+}=\mathrm{Cl}^{-}+\mathrm{Ca}^{2+} \\
& \mathrm{CaCl}_{2}(\mathrm{aq})=2 \mathrm{Cl}^{-}+\mathrm{Ca}^{2+} \\
& \mathrm{CaHCO}_{3}{ }^{+}=\mathrm{HCO}_{3}^{-}+\mathrm{Ca}^{2+} \\
& \mathrm{CaSO}_{4}(\mathrm{aq})=\mathrm{Ca}^{2+}+\mathrm{SO}_{4}{ }^{2-} \\
& \mathrm{H}_{2}(\mathrm{aq})+1 / 2 \mathrm{O}_{2}(\mathrm{aq})=\mathrm{H}_{2} \mathrm{O} \\
& \mathrm{H}_{2} \mathrm{~S}(\mathrm{aq})+2 \mathrm{O}_{2}(\mathrm{aq})=2 \mathrm{H}^{+}+\mathrm{SO}_{4}{ }^{2-} \\
& \mathrm{HCl}(\mathrm{aq})=\mathrm{H}^{+}+\mathrm{Cl}^{-} \\
& \mathrm{HO}_{2}{ }^{-}+\mathrm{H}^{+}=\mathrm{H}_{2} \mathrm{O}+1 / 2 \mathrm{O}_{2} \text { (aq) } \\
& \mathrm{HS}^{-}+2 \mathrm{O}_{2}(\mathrm{aq})=\mathrm{H}^{+}+\mathrm{SO}_{4}{ }^{2-} \\
& \mathrm{HSO}_{4}{ }^{-}=\mathrm{H}^{+}+\mathrm{SO}_{4}{ }^{2-} \\
& \mathrm{NaCO}_{3}{ }^{-}+\mathrm{H}^{+}=\mathrm{HCO}_{3}^{-}+\mathrm{Na}^{+} \\
& \mathrm{NaCl}(\mathrm{aq})=\mathrm{Cl}^{-}+\mathrm{Na}^{+} \\
& \mathrm{NaHCO}_{3}(\mathrm{aq})=\mathrm{HCO}_{3}^{-}+\mathrm{Na}^{+} \\
& \mathrm{NaOH}(\mathrm{aq})+\mathrm{H}^{+}=\mathrm{H}_{2} \mathrm{O}+\mathrm{Na}^{+} \\
& \mathrm{OH}^{-}+\mathrm{H}^{+}=\mathrm{H}_{2} \mathrm{O} \\
& \mathrm{S}^{2-}+2 \mathrm{O}_{2}(\mathrm{aq})=\mathrm{SO}_{4}{ }^{2-} \\
& \text { Solids } \\
& \mathrm{C}\left(\text { in } \mathrm{CH}_{2} \mathrm{O}\right)+\mathrm{H}_{2} \mathrm{O}+\mathrm{O}_{2}(\mathrm{aq})=\mathrm{HCO}_{3}^{-}+\mathrm{H}^{+} \\
& \mathrm{H}_{2} \mathrm{O} \text { (in } \mathrm{CH}_{2} \mathrm{O} \text { ) }=\mathrm{H}_{2} \mathrm{O} \\
& \mathrm{CaCO}_{3}+\mathrm{H}^{+}=\mathrm{HCO}_{3}^{-}+\mathrm{Ca}^{2+}
\end{aligned}
$$


Table 4 Chemical compositions of the seawaters used in the mixing calculations

\begin{tabular}{|c|c|c|c|c|}
\hline & & & Value & Units \\
\hline \multirow[t]{13}{*}{$\overline{S W_{1}}$} & \multirow[t]{5}{*}{ Aqueous species } & $\mathrm{Na}^{+}$ & 494.7 & $\mathrm{mmol} / \mathrm{L}$ \\
\hline & & $\mathrm{Cl}^{-}$ & 483.1 & $\mathrm{mmol} / \mathrm{L}$ \\
\hline & & $\mathrm{SO}_{4}^{2-}$ & 17.9 & $\mathrm{mmol} / \mathrm{L}$ \\
\hline & & $\mathrm{Ca}^{2+}$ & 13.1 & $\mathrm{mmol} / \mathrm{L}$ \\
\hline & & DIC & 3.5 & $\mathrm{mmol} / \mathrm{L}$ \\
\hline & Salinity & & 32.13 & $\mathrm{~g} / \mathrm{kg}$ \\
\hline & Density & & 1.03 & $\mathrm{~g} / \mathrm{cm}^{3}$ \\
\hline & Ionic strength & & 0.55 & \\
\hline & Carbonate alkalinity & & 2.98 & meq/L \\
\hline & Calcite saturation index & $(\Omega)$ & 0.49 & \\
\hline & Temperature & & 15 & ${ }^{\circ} \mathrm{C}$ \\
\hline & $\mathrm{pH}$ & & 7.0 & \\
\hline & $\delta^{13} C_{D I C}$ & & -10.1 & $\%$ \\
\hline \multirow[t]{13}{*}{$\mathrm{SW}_{2}$} & \multirow[t]{5}{*}{ Aqueous species } & $\mathrm{Na}^{+}$ & 492.8 & $\mathrm{mmol} / \mathrm{L}$ \\
\hline & & $\mathrm{Cl}^{-}$ & 483.0 & $\mathrm{mmol} / \mathrm{L}$ \\
\hline & & $\mathrm{SO}_{4}{ }^{2-}$ & 14.0 & $\mathrm{mmol} / \mathrm{L}$ \\
\hline & & $\mathrm{Ca}^{2+}$ & 13.2 & $\mathrm{mmol} / \mathrm{L}$ \\
\hline & & DIC & 11.8 & $\mathrm{mmol} / \mathrm{L}$ \\
\hline & Salinity & & 32.38 & $\mathrm{~g} / \mathrm{kg}$ \\
\hline & Density & & 1.03 & $\mathrm{~g} / \mathrm{cm}^{3}$ \\
\hline & Ionic strength & & 0.55 & \\
\hline & Carbonate alkalinity & & 9.15 & meq/L \\
\hline & Calcite saturation index & $(\Omega)$ & 1.00 & \\
\hline & Temperature & & 15 & ${ }^{\circ} \mathrm{C}$ \\
\hline & $\mathrm{pH}$ & & 6.8 & \\
\hline & $\delta^{13} C_{D I C}$ & & -21.2 & $\%$ \\
\hline \multirow[t]{13}{*}{$\mathrm{SW}_{3}$} & \multirow[t]{5}{*}{ Aqueous species } & $\mathrm{Na}^{+}$ & 485.7 & $\mathrm{mmol} / \mathrm{L}$ \\
\hline & & $\mathrm{Cl}^{-}$ & 482.6 & $\mathrm{mmol} / \mathrm{L}$ \\
\hline & & $\mathrm{SO}_{4}^{2-}$ & 0.0 & $\mathrm{mmol} / \mathrm{L}$ \\
\hline & & $\mathrm{Ca}^{2+}$ & 13.6 & $\mathrm{mmol} / \mathrm{L}$ \\
\hline & & DIC & 42.0 & $\mathrm{mmol} / \mathrm{L}$ \\
\hline & Salinity & & 33.28 & $\mathrm{~g} / \mathrm{kg}$ \\
\hline & Density & & 1.03 & $\mathrm{~g} / \mathrm{cm}^{3}$ \\
\hline & Ionic strength & & 0.53 & \\
\hline & Carbonate alkalinity & & 31.89 & meq/L \\
\hline & Calcite saturation index & $(\Omega)$ & 3.32 & \\
\hline & Temperature & & 15 & ${ }^{\circ} \mathrm{C}$ \\
\hline & $\mathrm{pH}$ & & 6.8 & \\
\hline & $\delta^{13} C_{D I C}$ & & -24.7 & $\%$ \\
\hline
\end{tabular}

to precipitate in calculations of the calcite saturation state and alkalinity during the reaction process. In the calculations, we used a default thermodynamic dataset (thermo.com.V8.R6.full) (Bethke 2008) with the B-dot activity model (Helgeson 1969; Helgeson and Kirkham 1974), while $\mathrm{Na}^{+}$was used to compensate for unbalanced charges in the initial seawater. We also calculated the $\delta^{13} C_{\text {DIC }}$ value in the seawater at each step assuming that the $\delta^{13} \mathrm{C}$ value of the remineralized organic carbon, added to the box by the anaerobic respiration, was -26 $\%$ based on the $\delta^{13} C_{\text {org }}$ records in the Mudstone Unit (Saitoh et al. 2014a). In addition, we mixed the initial seawater $\left(\mathrm{SW}_{i}\right)$ with the seawaters generated in the box by anaerobic respiration $\left(\mathrm{SW}_{1}, \mathrm{SW}_{2}, \mathrm{SW}_{3}\right)$, assuming mixing of the deep-water mass with the ambient seawater in the water column. The chemical compositions of $\mathrm{SW}_{1}, \mathrm{SW}_{2}$, and $\mathrm{SW}_{3}$ are shown in Table 4. Mixing ratios of the generated seawaters to $\mathrm{SW}_{i}$ are between 0 and 0.5. We then calculated the $\delta^{13} C_{\text {DIC }}$ value and calcite saturation index of the mixed waters.

\section{Results}

\section{Geologic setting and stratigraphy}

During the Permian, South China was located at low latitudes on the eastern side of Pangaea, where shallowmarine carbonates and terrigenous clastics with diverse fossils accumulated extensively on the continental shelves (Fig. 1b; Zhao et al. 1981; Scotese and Langford 1995; Jin et al. 1998). In northern Sichuan, along the northwestern edge of South China, carbonates and mudstones of relatively deep-water facies were thickly accumulated in a slope/basin environment (Fig. 1b; Wang and Jin 2000). At Chaotian, the Permo-Triassic rocks ( $>300 \mathrm{~m}$ thick in total) include the Guadalupian Maokou Formation, the Lopingian Wujiaping and Dalong formations, and the lowermost Triassic Feixianguan Formation, in ascending order (Fig. 1c; Isozaki et al. 2004, 2008; Saitoh et al. 2013a, 2013b, 2014b). The Maokou Formation, >150 m thick, consists mainly of massive dark gray bioclastic limestone with abundant shallow-marine fossils such as calcareous algae, brachiopods, and fusulines. The uppermost part ( 11 $\mathrm{m}$ thick) of the Maokou Formation is composed of thinly bedded black mudstone and chert containing radiolarians and conodonts. The Wujiaping Formation, $\sim 70 \mathrm{~m}$ thick, is composed mainly of massive dark gray bioclastic limestone containing shallow-marine fossils such as fusulines, calcareous algae, and brachiopods. The Dalong Formation, $\sim 25 \mathrm{~m}$ thick, is composed mainly of thinly bedded black mudstone and siliceous mudstone with abundant radiolarians. The Feixianguan Formation, $>30 \mathrm{~m}$ thick, is dominated by thinly bedded light gray micritic limestone containing few conodonts and ammonoids.

The Guadalupian-Lopingian boundary (G-LB) interval ( $\sim 30 \mathrm{~m}$ thick) analyzed here consists of three stratigraphic units: (1) the early Capitanian (Late Guadalupian) Limestone Unit of the Maokou Formation, (2) the early-late Capitanian Mudstone Unit of the Maokou Formation, and (3) the lower part of the early Wuchiapingian 
(Early Lopingian) Wujiaping Formation, in ascending order (Fig. 1c; Isozaki et al. 2008; Saitoh et al. 2013a). The Limestone Unit of the Maokou Formation, 11 m thick, is composed of bioclastic limestone with abundant shallowmarine fossils (e.g., calcareous algae, fusulines, and corals) deposited on a euphotic and oxic shelf. In contrast, the overlying Mudstone Unit, $\sim 11 \mathrm{~m}$ thick, is composed mainly of black calcareous mudstone, black chert/siliceous mudstone, and dark gray carbonates containing abundant radiolarians, conodonts, and ammonoids. This unit was deposited on a relatively deep disphotic slope/basin under anoxic conditions. The lower Wujiaping Formation, $11.5 \mathrm{~m}$ thick, is mainly bioclastic limestone with shallowmarine fossils including calcareous algae deposited on a euphotic and oxic shelf. A $\sim 2 \mathrm{~m}$ thick tuffaceous Wangpo bed occurs at the base of the Wujiaping Formation. The end-Guadalupian extinction horizon is assigned to the top of the Mudstone Unit, while the biostratigraphically defined G-LB is placed at the base of the lower Wujiaping bioclastic limestones based on index fossils such as conodonts, fusulines, radiolarians, and ammonoids.

\section{Petrology of the carbonate}

Characteristic carbonate crystals occur frequently in the Mudstone Unit of the Maokou Formation at Chaotian (Figs. 1c and 2). Their occurrence is limited to the unit of deep-water facies, and no similar crystals are observed in the underlying and overlying shallow-marine bioclastic limestones. The carbonate crystals form severalcentimeter-thick beds (5 $\mathrm{cm}$ on average) in multiple horizons in the Mudstone Unit (Fig. 2a, b). There are two major types of calcite crystal textures: "randomly oriented" and "bundled." In the first texture, monocrystalline calcite crystals $(\sim 200-300 \mu \mathrm{m}$ long $)$ occur in a randomly oriented manner within a bed (Fig. 2c). The aspect ratios (the ratio of the lengths of the long and short axes of a crystal) of these "randomly oriented" calcite crystals are largely $<5$, with no remarkable size variation. Each calcite crystal is consistently elongate along the $c$-axis of the trigonal system (Fig. 2c-e), yet the $c$-axes themselves are randomly, and therefore isotropically, oriented in a bed. However, in certain beds, the long axes of the crystals are generally perpendicular to the bedding (Fig. 2f, g). The matrix of the crystal beds is composed of very fine clay-sized silicate particles, recognized as dark areas on photomicrographs. In the second crystal texture type, $0.2-20 \mathrm{~mm}$ long monocrystalline calcite crystals are bundled together within a bed (Fig. 2h-k). These "bundled" calcite crystals are consistently elongate along the $c$-axis, and their aspect ratios are largely $>6$. The bundled crystals mainly grow upward and are consistently perpendicular to the bedding. Certain crystals originate from brachiopod shells contained in the bed and grow both upward and downward.
Inclusions of $1-2 \mu \mathrm{m}$ in size are aligned along grain boundaries in the bundled monocrystalline crystals. The bundled calcite crystals generally do not coexist with the randomly oriented crystals, although in some beds, the randomly oriented crystals gradually transition upward to bundled crystals (Fig. 2a). A small number of a third type of calcite crystal also occurs in the Mudstone Unit (Fig. 2b, k). Calcite crystals $<200 \mu \mathrm{m}$ long are densely packed in certain beds. These "packed" calcite crystals are also elongate along the $c$-axis, though their aspect ratios are low (primarily <3). The bedding of the packed crystal beds is wavy, and few bioclasts are contained within the beds. The results of XRD analyses show that the Chaotian carbonates are composed solely of calcite (Fig. 3).

\section{Isotopic composition of the carbonate}

Table 5 lists all the measured $\delta^{13} \mathrm{C}_{\text {carb }}$ and $\delta^{18} \mathrm{O}_{\text {carb }}$ values of the carbonates. Figure 4 shows stratigraphic profiles of the $\delta^{13} C_{\text {carb }}$ values, and Fig. 5 shows a cross-plot of the $\delta^{13} \mathrm{C}_{\text {carb }}$ and $\delta^{18} \mathrm{O}_{\text {carb }}$ values of the analyzed samples. The $\delta^{13} \mathrm{C}_{\text {carb }}$ values of the randomly oriented calcite crystals range from -6.6 to + $1.6 \%$, with an average value of approximately -0.8 $\%$. The $\delta^{13} \mathrm{C}_{\text {carb }}$ values of the bundled calcite crystals range from -6.7 to $+2.6 \%$, with an average value of approximately $-0.6 \%$. The $\delta^{13} C_{\text {carb }}$ values of the packed calcite crystals range from -11.7 to $-5.1 \%$, with an average value of approximately $-8.7 \%$. The $\delta^{18} \mathrm{O}_{\text {carb }}$ values of the randomly oriented calcite crystals range from -13.8 to $-3.5 \%$, with an average value of approximately $-6.7 \%$. The $\delta^{18} \mathrm{O}_{\text {carb }}$ values of the bundled calcite crystals range from -14.2 to $3.3 \%$, with an average value of approximately -7.1 $\%$. The $\delta^{18} \mathrm{O}_{\text {carb }}$ values of the packed calcite crystals range from -10.4 to $-4.9 \%$, with an average value of approximately $-7.3 \%$. No linear correlation is observed between the $\delta^{13} \mathrm{C}_{\text {carb }}$ and $\delta^{18} \mathrm{O}_{\text {carb }}$ values of each calcite type, suggesting that any diagenetic overprinting is not significant (Fig. 5; Knauth and Kennedy 2009), although some of the $\delta^{18} \mathrm{O}_{\text {carb }}$ values are considerably low and imply some diagenetic isotopic alteration. As described above, the analyzed carbonate crystals are monocrystalline calcite elongate along the $c$-axis. This mineralogical characteristic indicates that the carbonate crystals were not affected by dissolution/remineralization during diagenesis (as discussed in detail in the next section) and that secondary isotopic alteration of the carbonates by these processes was not significant. In each type of carbonate, most of the $\delta^{13} C_{\text {carb }}$ values are relatively high in the lower part and relatively low in the upper part of the Mudstone Unit. 

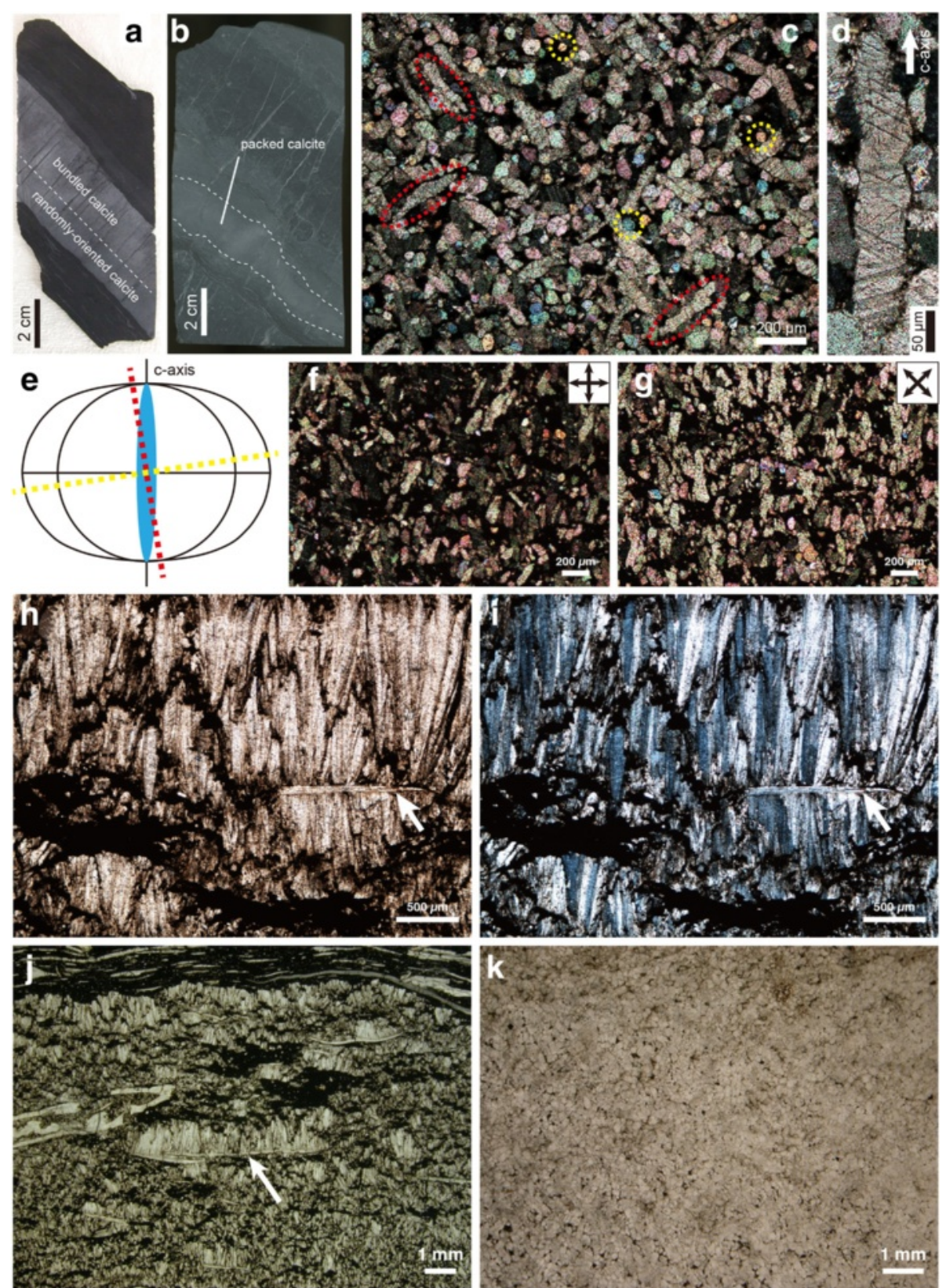

Fig. 2 Authigenic carbonates at Chaotian. a, b Drill core samples of a calcite crystal bed. In a, the lower and upper parts of the carbonate bed are composed of "randomly oriented" and "bundled" calcite crystals, respectively, and the bed is parallel to the overlying and underlying black mudstone beds. In b, "packed" calcite crystals form a wavy bed. c Photomicrograph of randomly oriented monocrystalline calcite crystals (crossed nicols). The horizontal direction corresponds to the bedding. Note that the interference colors of the elongate crystals (circled in red) are consistently high order (typical of calcite), whereas those of circular crystals (circled in yellow) are low order. $\mathbf{d}$ Enlarged photomicrograph of a crystal rotated $45^{\circ}$ relative to the bedding (crossed nicols). e Normal velocity curve of an optically negative uniaxial calcite. The optical characteristics of monocrystalline crystals in C show that the crystals are elongate along the $c$-axis because the interference color of calcite is determined by the angle between the $c$-axis and the cross section. When the angle is low (e.g., the cross section represented by the red dashed line in $\mathbf{e}$ ), the apparent shape of the crystals in thin section is elongate and the crystals' interference colors are high order (the crystals circled in red in c). The opposite is true for high-angle cross sections (the yellow dashed line in $\mathbf{e}$ and the circular crystals circled in yellow in c). $\mathbf{f}, \mathbf{g}$ Photomicrographs of the same sample from a calcite bed. The horizontal direction corresponds to the bedding. The crossed polarizer and analyzer in $\mathbf{f}$ and $\mathbf{g}$ are parallel/perpendicular to and rotated $45^{\circ}$ relative to the bedding, respectively. Note the contrast in brightness between the photos. This difference indicates that the crystals are largely perpendicular to the bedding because calcite exhibits straight extinction. $\mathbf{h}-\mathbf{j}$ Photomicrographs of the bundled calcites. $\mathbf{h}$ (opened nicols) and $\mathbf{i}$ (crossed nicols) show the same field of view. The horizontal direction corresponds to the bedding in each photo. Some bundled crystals grow from brachiopod shells (arrows) upward and partly downward. k Photomicrograph of packed calcite crystals (opened nicols). Up to $200 \mu \mathrm{m}$ long calcite crystals are densely packed in the bed 


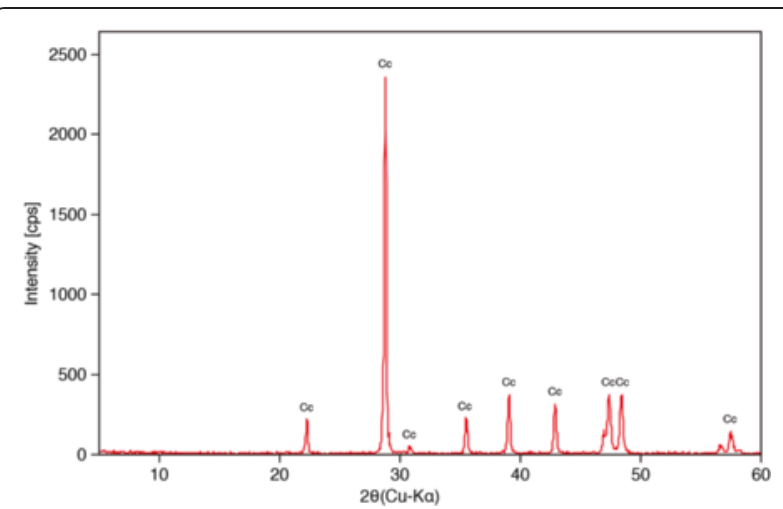

Fig. 3 Representative XRD pattern of the authigenic carbonates at Chaotian. The pattern shows that the carbonate is composed solely of calcite (Cc)

\section{Thermodynamic and mixing calculations}

Figure 6 shows calculated changes in the concentrations of inorganic carbon and sulfur chemical species, $\mathrm{pH}$, carbonate alkalinity, saturation index of calcite $(\Omega)$, and the $\delta^{13} C_{\text {DIC }}$ value in response to sulfate reduction in the hypothetical Permian seawater. The $\mathrm{pH}$ value decreases abruptly from the initial value 7.8 to 6.9 in the early stage of the reaction, in association with dissociation of hydrogen sulfide generated by sulfate reduction and an addition of $\mathrm{CO}_{2}$ species derived from decomposition of organic matter. It then remains nearly consistent, with values around 6.8, due to carbonate buffering in the middle to late stages. Carbonate alkalinity monotonously increases in response to sulfate reduction. Calcite is supersaturated under the initial conditions. In the early stage, calcite becomes undersaturated mainly due to the $\mathrm{pH}$ decrease, despite carbonate alkalinity increasing. Calcite is again supersaturated as alkalinity increases substantially in the late stage of the reaction. The $\delta^{13} C_{\text {DIC }}$ value in the seawater monotonously decreases to $-25 \%$ in response to sulfate reduction. The results of this study are generally consistent with those of Meister (2013), who examined carbonate saturation states as a result of sulfate reduction. The $\mathrm{pH}$, alkalinity, and $\Omega$ do not change significantly in response to denitrification, owing to the relatively low nitrate concentration (15 $\mu \mathrm{mol} / \mathrm{L})$ (results not shown).

We mixed the initial seawater $\left(S_{i}\right)$ with the seawaters generated by sulfate reduction $\left(\mathrm{SW}_{1}, \mathrm{SW}_{2}, \mathrm{SW}_{3}\right)$ (Fig. 6). Figure 7 shows the relationships between the $\delta^{13} C_{\text {DIC }}$ value and $\Omega$ of the mixed waters. When $S W_{1}$ is mixed with $\mathrm{SW}_{i}$, the $\Omega$ value gradually and monotonously decreases from $\sim 2.0$ to 0.5 according to an increase of the mixing ratio of $\mathrm{SW}_{1}$ to $\mathrm{SW}_{i}$ (from 0 to 0.5 ). When a small amount of $\mathrm{SW}_{2}$ is mixed with $\mathrm{SW}_{i}$, the mixed water becomes undersaturated with respect to calcite, possibly due to a $\mathrm{pH}$ decrease. The $\Omega$ value then gradually increases with increasing mixing ratios of $\mathrm{SW}_{2}$ to $\mathrm{SW}_{i}$ but does not reach 1.0 even when the mixing ratio is 0.5 . When $\mathrm{SW}_{3}$ is mixed with $\mathrm{SW}_{i}$, the $\Omega$ value also abruptly decreases to $\sim 0.5$ and then increases to $>1.0$ according to the increase in the mixing ratio. This is probably because of the high carbonate alkalinity of $\mathrm{SW}_{3}$ (>30 meq/L) although the $\mathrm{pH}$ of the water is $\sim 6.8$. The $\Omega$ value reaches $>3.0$ when the mixing ratio is 0.5 .

\section{Discussion}

\section{Authigenic carbonate precipitation at Chaotian}

The elongate morphology along the $c$-axis of the calcite crystals from Chaotian is an important feature that allows us to clarify their origin (Fig. 2c-k). This mineralogical characteristic suggests that the calcites were precipitated directly from oversaturated seawater, causing the calcite to grow along the $c$-axis. The Chaotian calcite crystals are neither bioclasts nor clastic grains, as it is unlikely that this remarkable mineralogical characteristic was generated by normal sedimentary processes. The possibility that the crystals were originally precipitated as other minerals, such as aragonite and gypsum, is also excluded because secondary calcite with a replacement origin usually exhibits a mosaic texture (e.g., Porter 2007), which is not the case for the monocrystalline calcites at Chaotian. Although apparently inconsistent with the general view that aragonite was preferentially precipitated (relative to calcite) in the Permian oceans (Sandberg 1983; Stanley and Hardie 1998), the calcite precipitation in the Chaotian section may have been caused by local "calcitic" conditions in the ocean of northwestern South China. No evidence for microbially induced precipitation of the crystals, such as "micropores" (Bosak et al. 2004), is recognized in the Chaotian carbonates.

Several lines of evidence suggest that the carbonate crystals at Chaotian were authigenically precipitated on the seafloor and/or within the soft sediments. The randomly oriented texture of the calcite crystals indicates that they were generated primarily on the seafloor and/ or within the soft sediments below the seafloor in the early diagenetic stage (Fig. 2c). In either case, the crystals were generated in situ and are not allochthonous. If the crystals were originally precipitated in shallower environments and secondarily transported to the deeper slope/basin by gravity flow, the long axis of each crystal should be aligned parallel to the bedding, which clearly differs from the observed randomly oriented texture of the Chaotian crystals. Similarly, it is unlikely that the crystals were originally generated in the water column and subsequently sank to the slope/basin. The texture of the bundled crystals clearly indicates that they were generated in situ (Fig. 2h-j). Moreover, certain bundled crystals were generated from brachiopod shells in a bed and grew both upward and downward. This texture, 
Table 5 Results of carbon and oxygen isotope analyses

\begin{tabular}{|c|c|c|c|c|c|}
\hline Unit/Fm & Sample ID & Type & Thickness (m) & $\delta^{13} C_{V P D B}$ & $\delta^{18} \mathrm{O}_{V P D B}$ \\
\hline Mudstone Unit of the Maokou Fm & E83-41 & bundled calcite & 10.54 & -2.5 & -9.2 \\
\hline Mudstone Unit of the Maokou Fm & $\mathrm{E} 83-40$ & bundled calcite & 10.54 & -2.4 & -4.5 \\
\hline Mudstone Unit of the Maokou Fm & E83-39 & bundled calcite & 10.54 & -3.0 & -8.9 \\
\hline Mudstone Unit of the Maokou Fm & E83-38 & bundled calcite & 10.54 & -2.1 & -4.6 \\
\hline Mudstone Unit of the Maokou Fm & E83-37 & bundled calcite & 10.53 & -1.7 & -9.3 \\
\hline Mudstone Unit of the Maokou Fm & E83-36 & bundled calcite & 10.53 & -2.4 & -5.7 \\
\hline Mudstone Unit of the Maokou Fm & E83-35 & bundled calcite & 10.53 & -1.6 & -10.7 \\
\hline Mudstone Unit of the Maokou Fm & E83-34 & bundled calcite & 10.53 & -2.1 & -10.6 \\
\hline Mudstone Unit of the Maokou Fm & E83-33 & bundled calcite & 10.53 & -2.0 & -7.8 \\
\hline Mudstone Unit of the Maokou Fm & E83-32 & bundled calcite & 10.52 & -2.1 & -4.1 \\
\hline Mudstone Unit of the Maokou Fm & E83-31 & bundled calcite & 10.52 & -1.8 & -9.3 \\
\hline Mudstone Unit of the Maokou Fm & E83-30 & bundled calcite & 10.52 & -1.8 & -10.3 \\
\hline Mudstone Unit of the Maokou Fm & E83-29 & bundled calcite & 10.52 & -0.8 & -5.4 \\
\hline Mudstone Unit of the Maokou Fm & $\mathrm{E} 83-28$ & bundled calcite & 10.52 & -0.4 & -7.9 \\
\hline Mudstone Unit of the Maokou Fm & E83-27 & bundled calcite & 10.51 & 0.0 & -5.5 \\
\hline Mudstone Unit of the Maokou Fm & E83-26 & bundled calcite & 10.51 & -0.5 & -7.2 \\
\hline Mudstone Unit of the Maokou Fm & E83-25 & bundled calcite & 10.51 & -0.6 & -8.1 \\
\hline Mudstone Unit of the Maokou Fm & E83-24 & bundled calcite & 10.51 & -0.3 & -4.4 \\
\hline Mudstone Unit of the Maokou Fm & E83-23 & bundled calcite & 10.51 & -0.6 & -5.9 \\
\hline Mudstone Unit of the Maokou Fm & E83-22 & bundled calcite & 10.50 & -0.6 & -6.2 \\
\hline Mudstone Unit of the Maokou Fm & E83-21 & bundled calcite & 10.50 & -0.9 & -5.3 \\
\hline Mudstone Unit of the Maokou Fm & E83-20 & bundled calcite & 10.50 & -0.7 & -10.0 \\
\hline Mudstone Unit of the Maokou Fm & E83-19 & bundled calcite & 10.50 & -0.9 & -10.3 \\
\hline Mudstone Unit of the Maokou Fm & E83-18 & bundled calcite & 10.50 & -0.7 & -5.9 \\
\hline Mudstone Unit of the Maokou Fm & E83-17 & bundled calcite & 10.49 & -0.7 & -5.4 \\
\hline Mudstone Unit of the Maokou Fm & E83-16 & packed calcite & 10.49 & -8.7 & -8.4 \\
\hline Mudstone Unit of the Maokou Fm & E83-15 & packed calcite & 10.49 & -9.5 & -7.9 \\
\hline Mudstone Unit of the Maokou Fm & E83-14 & packed calcite & 10.49 & -9.1 & -6.9 \\
\hline Mudstone Unit of the Maokou Fm & E83-13 & packed calcite & 10.49 & -10.6 & -8.3 \\
\hline Mudstone Unit of the Maokou Fm & E83-12 & packed calcite & 10.48 & -7.5 & -8.5 \\
\hline Mudstone Unit of the Maokou Fm & E83-11 & packed calcite & 10.48 & -11.7 & -10.4 \\
\hline Mudstone Unit of the Maokou Fm & E83-10 & packed calcite & 10.48 & -10.2 & -9.4 \\
\hline Mudstone Unit of the Maokou Fm & E83-9 & bundled calcite & 10.48 & -0.1 & -6.8 \\
\hline Mudstone Unit of the Maokou Fm & E83-8 & bundled calcite & 10.48 & -0.7 & -5.7 \\
\hline Mudstone Unit of the Maokou Fm & E83-7 & bundled calcite & 10.47 & -0.4 & -4.4 \\
\hline Mudstone Unit of the Maokou Fm & E83-6 & bundled calcite & 10.47 & -0.1 & -4.5 \\
\hline Mudstone Unit of the Maokou Fm & E83-5 & bundled calcite & 10.47 & -0.1 & -7.0 \\
\hline Mudstone Unit of the Maokou Fm & E83-4 & bundled calcite & 10.47 & -0.4 & -4.1 \\
\hline Mudstone Unit of the Maokou Fm & E83-3 & bundled calcite & 10.47 & -0.3 & -4.2 \\
\hline Mudstone Unit of the Maokou Fm & E83-2 & bundled calcite & 10.46 & -0.2 & -5.3 \\
\hline Mudstone Unit of the Maokou Fm & E83-1 & bundled calcite & 10.46 & -1.4 & -7.4 \\
\hline Mudstone Unit of the Maokou Fm & E65-7 & bundled calcite & 10.11 & -0.9 & -3.3 \\
\hline Mudstone Unit of the Maokou Fm & E65-6 & bundled calcite & 10.11 & -1.0 & -3.7 \\
\hline Mudstone Unit of the Maokou Fm & E65-5 & bundled calcite & 10.11 & -1.1 & -3.9 \\
\hline
\end{tabular}


Table 5 Results of carbon and oxygen isotope analyses (Continued)

\begin{tabular}{|c|c|c|c|c|c|}
\hline Mudstone Unit of the Maokou Fm & E65-4 & packed calcite & 10.10 & -9.6 & -6.1 \\
\hline Mudstone Unit of the Maokou Fm & E65-3 & packed calcite & 10.10 & -8.7 & -4.9 \\
\hline Mudstone Unit of the Maokou Fm & E65-2 & packed calcite & 10.10 & -9.1 & -5.6 \\
\hline Mudstone Unit of the Maokou Fm & E65-1 & packed calcite & 10.10 & -9.6 & -6.1 \\
\hline Mudstone Unit of the Maokou Fm & E54 & bundled calcite & 9.73 & -6.7 & -8.8 \\
\hline Mudstone Unit of the Maokou Fm & E31-7 & randomly oriented calcite & 9.02 & -0.3 & -7.7 \\
\hline Mudstone Unit of the Maokou Fm & E31-6 & randomly oriented calcite & 9.01 & -0.5 & -6.4 \\
\hline Mudstone Unit of the Maokou Fm & E31-5 & randomly oriented calcite & 9.00 & -0.6 & -4.7 \\
\hline Mudstone Unit of the Maokou Fm & E31-4 & randomly oriented calcite & 8.99 & -0.7 & -8.1 \\
\hline Mudstone Unit of the Maokou Fm & E31-3 & randomly oriented calcite & 8.98 & -0.7 & -4.7 \\
\hline Mudstone Unit of the Maokou Fm & E31-2 & randomly oriented calcite & 8.97 & -0.7 & -4.9 \\
\hline Mudstone Unit of the Maokou Fm & E31-1 & randomly oriented calcite & 8.96 & -0.6 & -5.4 \\
\hline Mudstone Unit of the Maokou Fm & E23R14 & bundled calcite & 8.75 & -1.4 & -8.8 \\
\hline Mudstone Unit of the Maokou Fm & $\mathrm{E} 23 \mathrm{R} 13$ & bundled calcite & 8.75 & -1.2 & -8.4 \\
\hline Mudstone Unit of the Maokou Fm & E23R12 & bundled calcite & 8.75 & -0.4 & -7.7 \\
\hline Mudstone Unit of the Maokou Fm & E23R11 & bundled calcite & 8.74 & -0.9 & -10.5 \\
\hline Mudstone Unit of the Maokou Fm & E23R10 & bundled calcite & 8.74 & -1.3 & -11.4 \\
\hline Mudstone Unit of the Maokou Fm & E23R9 & bundled calcite & 8.74 & -0.3 & -14.2 \\
\hline Mudstone Unit of the Maokou Fm & E23R8 & bundled calcite & 8.74 & -0.1 & -10.1 \\
\hline Mudstone Unit of the Maokou Fm & E23R7 & bundled calcite & 8.74 & -0.6 & -12.3 \\
\hline Mudstone Unit of the Maokou Fm & E23R6 & bundled calcite & 8.73 & -0.8 & -7.3 \\
\hline Mudstone Unit of the Maokou Fm & E23R5 & randomly oriented calcite & 8.73 & -1.4 & -7.9 \\
\hline Mudstone Unit of the Maokou Fm & E23R4 & randomly oriented calcite & 8.73 & -0.7 & -5.6 \\
\hline Mudstone Unit of the Maokou Fm & E23R3 & randomly oriented calcite & 8.73 & -1.0 & -5.7 \\
\hline Mudstone Unit of the Maokou Fm & $\mathrm{E} 23 \mathrm{R} 2$ & randomly oriented calcite & 8.73 & -0.8 & -8.8 \\
\hline Mudstone Unit of the Maokou Fm & E23R1 & randomly oriented calcite & 8.72 & -0.7 & -7.3 \\
\hline Mudstone Unit of the Maokou Fm & E1-10 & randomly oriented calcite & 8.32 & -1.7 & -4.5 \\
\hline Mudstone Unit of the Maokou Fm & E1-9 & randomly oriented calcite & 8.31 & -1.3 & -4.9 \\
\hline Mudstone Unit of the Maokou Fm & E1-8 & randomly oriented calcite & 8.31 & -1.4 & -9.3 \\
\hline Mudstone Unit of the Maokou Fm & E1-7 & randomly oriented calcite & 8.31 & -1.3 & -7.7 \\
\hline Mudstone Unit of the Maokou Fm & E1-6 & randomly oriented calcite & 8.31 & -0.8 & -4.9 \\
\hline Mudstone Unit of the Maokou Fm & E1-5 & randomly oriented calcite & 8.30 & -0.6 & -13.8 \\
\hline Mudstone Unit of the Maokou Fm & E1-4 & randomly oriented calcite & 8.30 & -0.6 & -6.1 \\
\hline Mudstone Unit of the Maokou Fm & E1-3 & randomly oriented calcite & 8.30 & -0.9 & -6.3 \\
\hline Mudstone Unit of the Maokou Fm & E1-2 & randomly oriented calcite & 8.29 & -1.2 & -8.3 \\
\hline Mudstone Unit of the Maokou Fm & E1-1 & randomly oriented calcite & 8.29 & -1.4 & -8.3 \\
\hline Mudstone Unit of the Maokou Fm & D120-4 & packed calcite & 8.17 & -6.3 & -6.4 \\
\hline Mudstone Unit of the Maokou Fm & D120-3 & packed calcite & 8.17 & -5.9 & -6.4 \\
\hline Mudstone Unit of the Maokou Fm & D120-2 & packed calcite & 8.16 & -5.1 & -7.1 \\
\hline Mudstone Unit of the Maokou Fm & D120-1 & randomly oriented calcite & 8.16 & -0.6 & -4.9 \\
\hline Mudstone Unit of the Maokou Fm & D98 & randomly oriented calcite & 7.41 & 0.7 & -4.8 \\
\hline Mudstone Unit of the Maokou Fm & D84.5 & randomly oriented calcite & 6.95 & 0.3 & -10.0 \\
\hline Mudstone Unit of the Maokou Fm & D70.6 & bundled calcite & 6.39 & 0.0 & -6.6 \\
\hline Mudstone Unit of the Maokou Fm & D70.5 & randomly oriented calcite & 6.38 & 0.8 & -3.5 \\
\hline Mudstone Unit of the Maokou Fm & D60-4 & randomly oriented calcite & 6.14 & 0.0 & -6.0 \\
\hline
\end{tabular}


Table 5 Results of carbon and oxygen isotope analyses (Continued)

\begin{tabular}{|c|c|c|c|c|c|}
\hline Mudstone Unit of the Maokou Fm & D60-3 & randomly oriented calcite & 6.13 & 0.6 & -9.9 \\
\hline Mudstone Unit of the Maokou Fm & D60-2 & randomly oriented calcite & 6.13 & 0.8 & -7.7 \\
\hline Mudstone Unit of the Maokou Fm & D60-1 & randomly oriented calcite & 6.12 & 0.2 & -8.0 \\
\hline Mudstone Unit of the Maokou Fm & D22-2 & randomly oriented calcite & 4.50 & -6.6 & -6.8 \\
\hline Mudstone Unit of the Maokou Fm & D22-1 & randomly oriented calcite & 4.49 & -6.6 & -5.7 \\
\hline Mudstone Unit of the Maokou Fm & C54-4 & bundled calcite & 2.95 & 1.7 & -10.3 \\
\hline Mudstone Unit of the Maokou Fm & C54-3 & bundled calcite & 2.94 & 2.3 & -4.2 \\
\hline Mudstone Unit of the Maokou Fm & C54-2 & bundled calcite & 2.94 & 2.4 & -4.6 \\
\hline Mudstone Unit of the Maokou Fm & C54-1 & bundled calcite & 2.94 & 2.6 & -3.5 \\
\hline Mudstone Unit of the Maokou Fm & $\mathrm{C} 43$ & bundled calcite & 2.62 & 1.3 & -11.6 \\
\hline Mudstone Unit of the Maokou Fm & C28-5 & bundled calcite & 2.09 & 1.4 & -10.5 \\
\hline Mudstone Unit of the Maokou Fm & C28-4 & bundled calcite & 2.09 & 1.6 & -4.8 \\
\hline Mudstone Unit of the Maokou Fm & $\mathrm{C} 28-3$ & bundled calcite & 2.09 & 1.9 & -4.8 \\
\hline Mudstone Unit of the Maokou Fm & $\mathrm{C} 28-2$ & bundled calcite & 2.09 & 2.3 & -3.5 \\
\hline Mudstone Unit of the Maokou Fm & C28-1 & bundled calcite & 2.09 & 1.8 & -4.2 \\
\hline Mudstone Unit of the Maokou Fm & C9-4 & randomly oriented calcite & 1.64 & -5.8 & -8.6 \\
\hline Mudstone Unit of the Maokou Fm & C9-3 & randomly oriented calcite & 1.63 & -4.3 & -6.4 \\
\hline Mudstone Unit of the Maokou Fm & C9-2 & randomly oriented calcite & 1.62 & -6.2 & -6.2 \\
\hline Mudstone Unit of the Maokou Fm & C9-1 & randomly oriented calcite & 1.61 & -6.3 & -6.2 \\
\hline Mudstone Unit of the Maokou Fm & B27 & randomly oriented calcite & 1.37 & 0.3 & -4.3 \\
\hline Mudstone Unit of the Maokou Fm & B18-5 & randomly oriented calcite & 1.07 & 1.6 & -4.4 \\
\hline Mudstone Unit of the Maokou Fm & B18-4 & randomly oriented calcite & 1.07 & 1.5 & -9.9 \\
\hline Mudstone Unit of the Maokou Fm & B18-3 & randomly oriented calcite & 1.07 & 1.6 & -9.1 \\
\hline Mudstone Unit of the Maokou Fm & B18-2 & randomly oriented calcite & 1.07 & 1.3 & -6.2 \\
\hline Mudstone Unit of the Maokou Fm & B18-1 & randomly oriented calcite & 1.07 & 1.4 & -6.5 \\
\hline Mudstone Unit of the Maokou Fm & B16-8 & randomly oriented calcite & 1.06 & 1.0 & -4.5 \\
\hline Mudstone Unit of the Maokou Fm & B16-7 & randomly oriented calcite & 1.06 & 1.0 & -4.7 \\
\hline Mudstone Unit of the Maokou Fm & B16-6 & randomly oriented calcite & 1.05 & 1.0 & -4.5 \\
\hline Mudstone Unit of the Maokou Fm & B16-5 & randomly oriented calcite & 1.05 & 0.8 & -4.6 \\
\hline Mudstone Unit of the Maokou Fm & B16-4 & randomly oriented calcite & 1.04 & 0.7 & -4.7 \\
\hline Mudstone Unit of the Maokou Fm & B16-3 & randomly oriented calcite & 1.04 & 0.7 & -8.0 \\
\hline Mudstone Unit of the Maokou Fm & B16-2 & randomly oriented calcite & 1.03 & 0.6 & -9.0 \\
\hline Mudstone Unit of the Maokou Fm & B16-1 & randomly oriented calcite & 1.03 & 0.6 & -8.2 \\
\hline
\end{tabular}

particularly the downward growth, strongly suggests that the bundled crystals grew from the shells within the sediments. The packed calcite crystal beds contain few bioclasts, and it is unlikely that they are allochthonous carbonate debris flow deposits (Fig. 2k). The wavy bedding of the packed crystal beds may imply that they were generated below the seafloor, pushing the upper and lower sediments up and down, respectively, in an early diagenetic stage (Fig. 2b). The consistent $c$-axis elongation of all the Chaotian calcite crystals suggests that no solid obstacle prevented growth during crystallization; the crystals likely precipitated in a free space and/or soft sediments.
The occurrence of the carbonate crystals in the Mudstone Unit at Chaotian corresponds stratigraphically to anoxic conditions and water-mass anaerobic respiration in the unit (Fig. 1c). Saitoh et al. (2013a) suggested that the Mudstone Unit was deposited under anoxic conditions based on the absence of bioturbation, high total organic carbon contents (up to $16 \%$ ), and abundant pyrite framboids. An anoxic water mass likely developed in the deep part of the water column, although the surface ocean may have remained oxic. Moreover, Saitoh et al. (2014a) reported the nitrogen and sulfur isotope records of the Mudstone Unit. The substantially high $\delta^{15} \mathrm{~N}$ values (up to $+14 \%$ ) and consistently low $\delta^{34} \mathrm{~S}$ values 


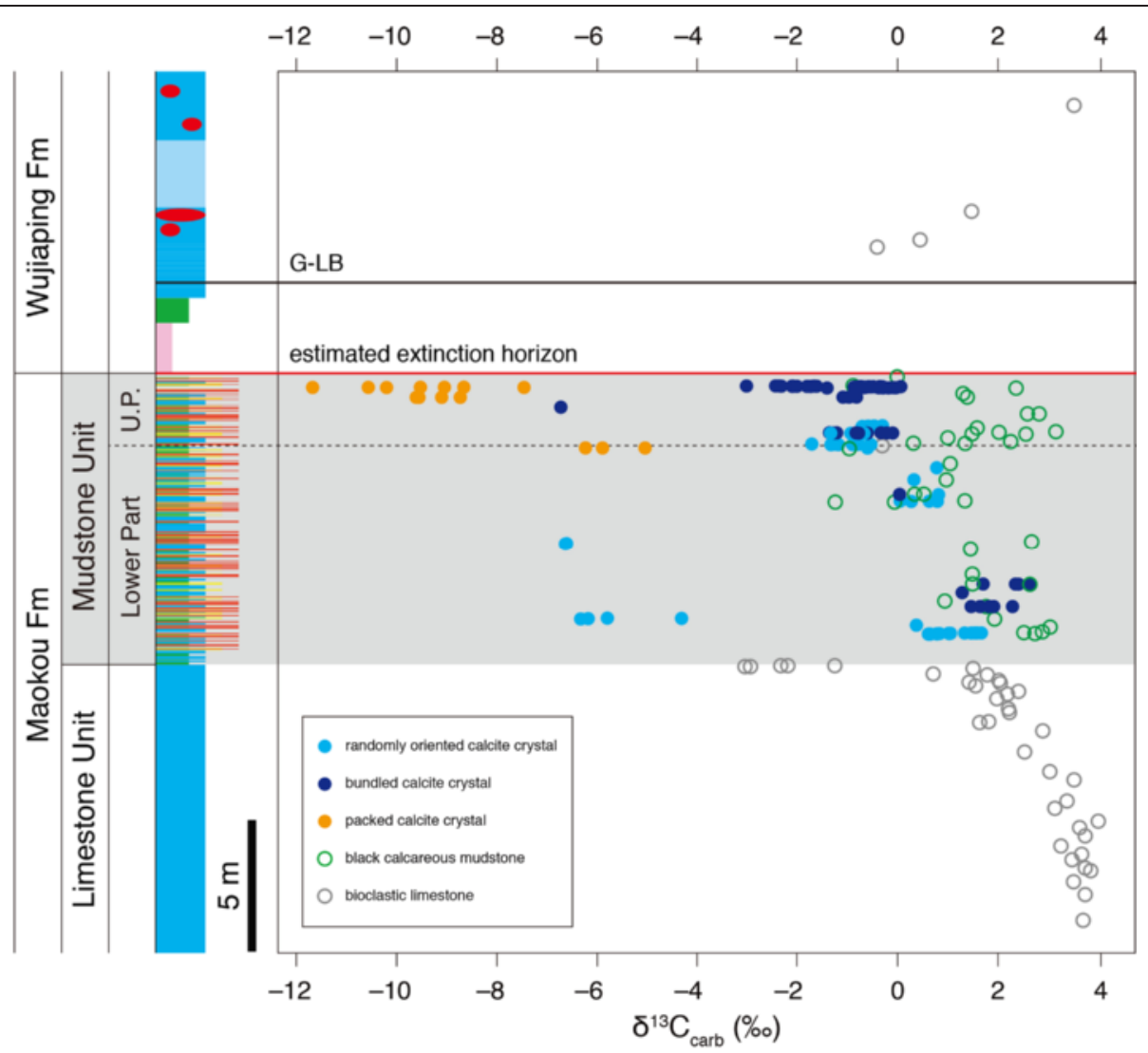

Fig. 4 Chemostratigraphic profile of the $\delta^{13} C_{\text {carb }}$ values of the authigenic carbonates at Chaotian. The $\delta^{13} C_{\text {carb }}$ values of the bioclastic limestone and black calcareous mudstone (open circles) were reported in Saitoh et al. (2013b). Except for some samples with lower values, the $\delta^{13} C_{\text {carb }}$ values of the carbonates are similar to or slightly lower than those of the black mudstone. U.P. upper part

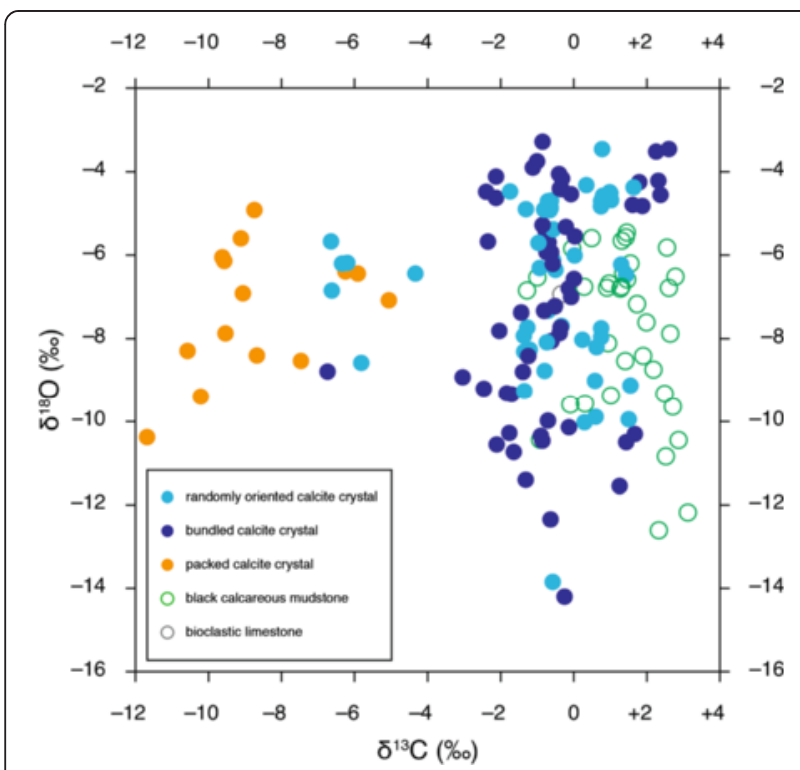

Fig. 5 Relationship between the $\delta^{18} \mathrm{O}_{\text {carb }}$ and $\delta^{13} \mathrm{C}_{\text {carb }}$ values of the authigenic carbonates at Chaotian (approximately $-37 \%$ ) in the unit indicate denitrification and sulfate reduction, respectively, in the anoxic deep waters. The clear stratigraphic correspondence implies that the authigenic carbonates at Chaotian may have precipitated in association with the water-mass anaerobic respiration.

\section{Carbon isotopic composition of the carbonate}

The inorganic carbon isotopic compositions of the authigenic carbonates at Chaotian are useful for identifying the carbon source of the carbonates. Generally, there are three potential carbon sources for authigenic carbonate: (1) seawater DIC, (2) remineralized organic carbon, and (3) remineralized methane carbon. The $\delta^{13} C_{\text {DIC }}$ value of the seawater is estimated to be approximately $+2 \%$ based on the $\delta^{13} \mathrm{C}_{\text {carb }}$ records of black mudstone in the Mudstone Unit in which carbonates are exclusively fragmented bioclasts of shallow-marine fossils (Fig. 4; Saitoh et al. 2013b). The $\delta^{13} \mathrm{C}$ values of the organic carbon in the Mudstone Unit are approximately $-26 \%$ (Saitoh et al. 2014a). The $\delta^{13} \mathrm{C}$ value of biogenic methane is generally extremely low (less than $-40 \%$; Whiticar 1999). The $\delta^{13} C_{\text {carb }}$ values of 
the authigenic carbonates at Chaotian were most likely determined by a degree of mixing of these three carbon sources. In the lower part of the Mudstone Unit, the $\delta^{13} \mathrm{C}_{\text {carb }}$ values of the randomly oriented and bundled calcite crystals are largely +1 to $+2 \%$ and are almost the same as or slightly lower than those of the black mudstone (Fig. 4). These observations indicate that almost all the carbon in these calcites was derived from the seawater DIC. In the upper part of the Mudstone Unit, the $\delta^{13} \mathrm{C}_{\text {carb }}$ values of the randomly oriented and bundled calcites are largely about $-1 \%$ (Figs. 4 and 5 ). These $\delta^{13} C_{\text {carb }}$ values suggest that $>80 \%$ of the carbon in these calcites was also derived from the seawater DIC. The main carbon source of the randomly oriented and bundled calcites in the Mudstone Unit is likely the seawater DIC. Although the textures of the randomly oriented and bundled calcite crystals suggest that the crystals may have grown within the sediments, these carbonates precipitated primarily in an open system with respect to carbonate, likely on the seafloor and/or immediately below the sediment-water interface.

The $\delta^{13} \mathrm{C}_{\text {carb }}$ values of the packed calcites are clearly lower (ranging from -12 to $-4 \%$ ) than those of the randomly oriented and bundled calcites (Figs. 4 and 5). The low $\delta^{13} \mathrm{C}_{\text {carb }}$ values are attributed to greater contributions of ${ }^{13} \mathrm{C}$-depleted remineralized carbon from decomposed organic matter and/or methane. The packed calcite crystals may have grown within the deep part of the sediments in a relatively closed system with respect to carbonate. The wavy bedding of the packed crystal beds suggests that the carbonates were generated within the sediments, which is consistent with their relatively low $\delta^{13} C_{\text {carb }}$ values (Fig. 2b). In ancient and modern oceans, the $\delta^{13} \mathrm{C}_{\text {carb }}$ values of certain authigenic carbonates are relatively high due to methanogenesis in the sediments (e.g., Naehr et al. 2007; Heindel et al. 2015; Li et al. 2015). Microbial methanogenesis enriches the residual pore water within the sediments in ${ }^{13} \mathrm{C}$, representing another potential mechanism for the relatively high $\delta^{13} C_{\text {carb }}$ values of the randomly oriented and bundled calcites at Chaotian. However, when authigenic carbonates are precipitated in sediments in which methanogenesis occurs, the $\delta^{13} C_{\text {carb }}$ values vary widely (up to 80 $\%$ ) due to methane production and its subsequent anaerobic oxidation, as is observed in modern oceans (e.g., Meister et al. 2007; Naehr et al. 2007). In marked contrast, the $\delta^{13} \mathrm{C}_{\text {carb }}$ values of the randomly oriented and bundled calcites at Chaotian largely fall within the relatively narrow range of -2 to $+2 \%$ (Figs. 4 and 5). Only certain carbonates, including the packed calcites, exhibit relatively low $\delta^{13} \mathrm{C}_{\text {carb }}$ values (less than $-4 \%$ ). It is therefore unlikely that the observed carbon isotopic variations at Chaotian were caused by methanogenesis in the sediments.

The water-mass anaerobic respiration in the Mudstone Unit at Chaotian, as suggested by the nitrogen and sulfur isotope records, implies that remineralized carbon with a relatively low $\delta^{13} \mathrm{C}$ value was released from suspended organic matter into the water column by the respiration. This ${ }^{13} \mathrm{C}$-depleted carbon would have markedly decreased the $\delta^{13} C_{\text {DIC }}$ value in the deep-water mass in the water column (Fig. 6). However, the $\delta^{13} C_{\text {carb }}$ records of the authigenic carbonates imply that the $\delta^{13} C_{\text {DIC }}$ values in the deep-water mass at Chaotian were likely +1 to $+2 \%$ in the lower part and approximately $-1 \%$ in the upper part of the Mudstone Unit (Fig. 4). The vertical $\delta^{13} \mathrm{C}_{\mathrm{DIC}}$ gradients in the water column between the surface oceans and the deep-water mass were likely $<1$ and $<3 \%$ in the lower and upper parts of the unit, respectively. The upper part of the Mudstone Unit was probably deposited on the deeper slope/basin than the lower part of the unit due to a relative deepening (Fig. 1c; Saitoh et al. 2013a). The $\delta^{13} \mathrm{C}_{\text {DIC }}$ value of the anoxic deep water in the upper part of the Mudstone Unit was lower than the value in the lower part of the unit. The estimated vertical $\delta^{13} \mathrm{C}_{\text {DIC }}$ gradients in the water column at Chaotian $(<3 \%)$ are similar to those in the modern and ancient oceans in the Phanerozoic (e.g., Kroopnick 1985; Kennett and Stott 1991; Huber et al. 1995; D'Hondt 2005). Although the $\delta^{13} \mathrm{C}_{\text {DIC }}$ value in the deep water is lower than the value of the surface oceans as previously suggested at Chaotian (Saitoh et al. 2013b), our results demonstrate that the $\delta^{13} C_{\text {DIC }}$ value in the deep-water mass was not decreased remarkably by the addition of remineralized carbon released from the suspended organic matter by the watermass anaerobic respiration. The relatively high $\delta^{13} \mathrm{C}_{\text {carb }}$ values of the Chaotian authigenic carbonates suggest that the ${ }^{13} \mathrm{C}$-depleted carbon released from the organic matter into the water column was quickly mixed with and diluted by a large DIC pool in the ocean. The addition of the remineralized organic carbon with low $\delta^{13} \mathrm{C}$ values may have had only a small influence on the carbon isotopic composition of the large DIC pool.

The mixing of seawaters in the water column, suggested by the relatively high $\delta^{13} C_{\text {carb }}$ values of the Chaotian carbonates, is in concordance with our calculated results (Figs. 6 and 7). The thermodynamic calculations show that, although a deep-water mass would have become undersaturated locally with respect to carbonate in the early stage of the reaction, the successive sulfate reduction elevates alkalinity and $\Omega$ values, driving carbonate precipitation (Fig. 6). Moreover, the mixing calculations demonstrate that all of the $\delta^{13} C_{\text {carb }}$ values of the Chaotian carbonates can be explained by the mixing of the hypothetical Permian seawater $\left(\mathrm{SW}_{i}\right)$ with the deep-water masses where sulfate reduction had occurred $\left(\mathrm{SW}_{1}\right.$ and $\left.\mathrm{SW}_{3}\right)$ (Fig. 7). The deep-water mass undersaturated with carbonate locally generated by the watermass sulfate reduction could be diluted by the ambient seawater that is supersaturated with respect to carbonate, 


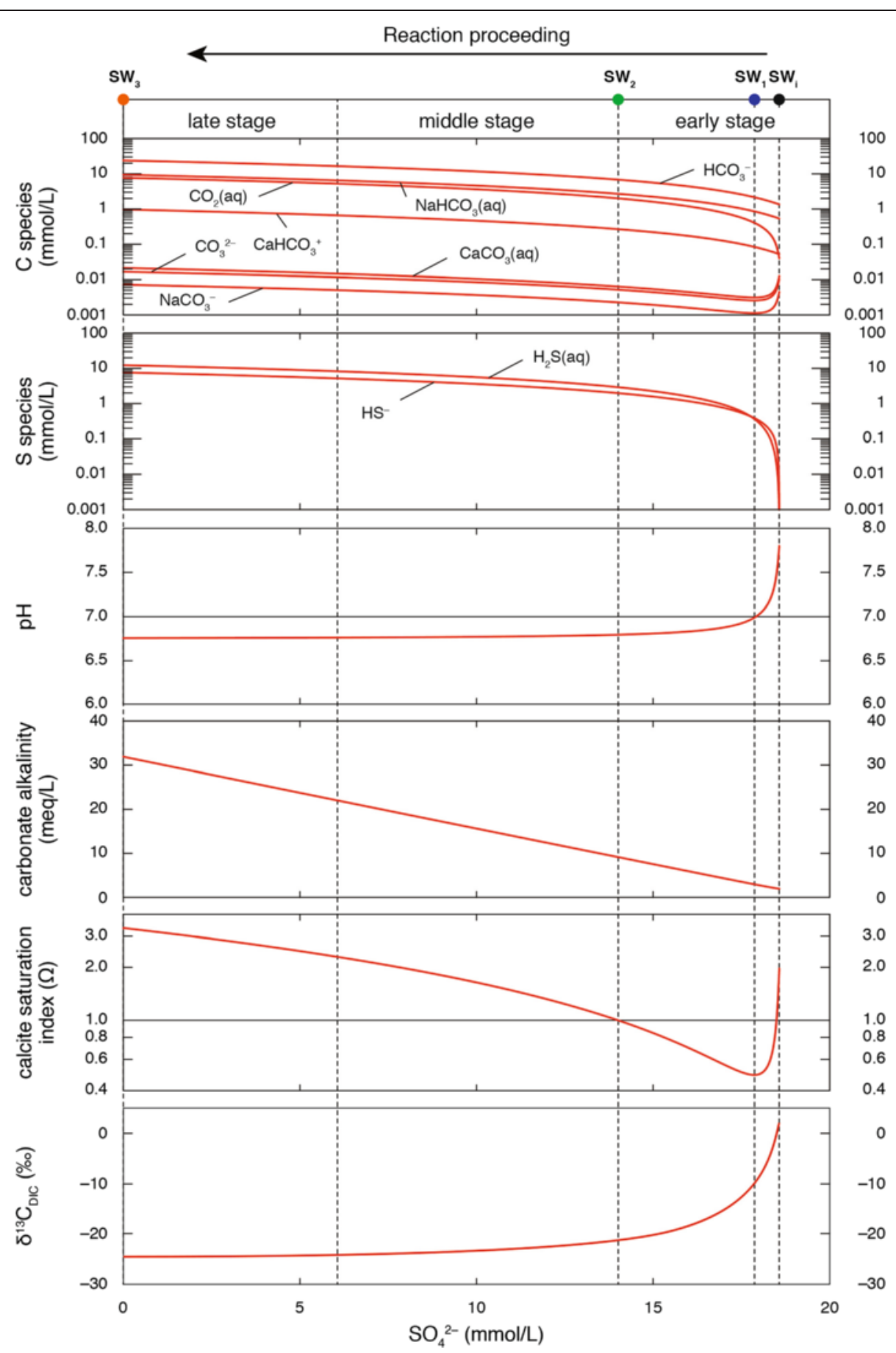

Fig. 6 Changes in the concentrations of inorganic carbon and sulfur chemical species, $\mathrm{pH}$, carbonate alkalinity, calcite saturation index, and the $\delta^{13} \mathrm{C}_{\mathrm{DIC}}$ values in response to sulfate reduction in the hypothetical Permian seawater

stimulating the precipitation of the randomly oriented and bundled calcites at Chaotian. The mixing calculation results are also consistent with the greater contributions of ${ }^{13} \mathrm{C}$-depleted remineralized organic carbon to certain carbonates with relatively low $\delta^{13} C_{\text {carb }}$ values, including the packed calcites, that were possibly generated within the sediments (Fig. 7). The relatively deep disphotic slope setting at Chaotian on the northwestern edge of South China at low latitudes might have been favorable to the seawater mixing by deep-water upwelling along the continental margin (Van der Kooij et al. 2010; Saitoh et al. 2013b). Moreover, Higgins et al. (2009) suggested that, in the ancient 


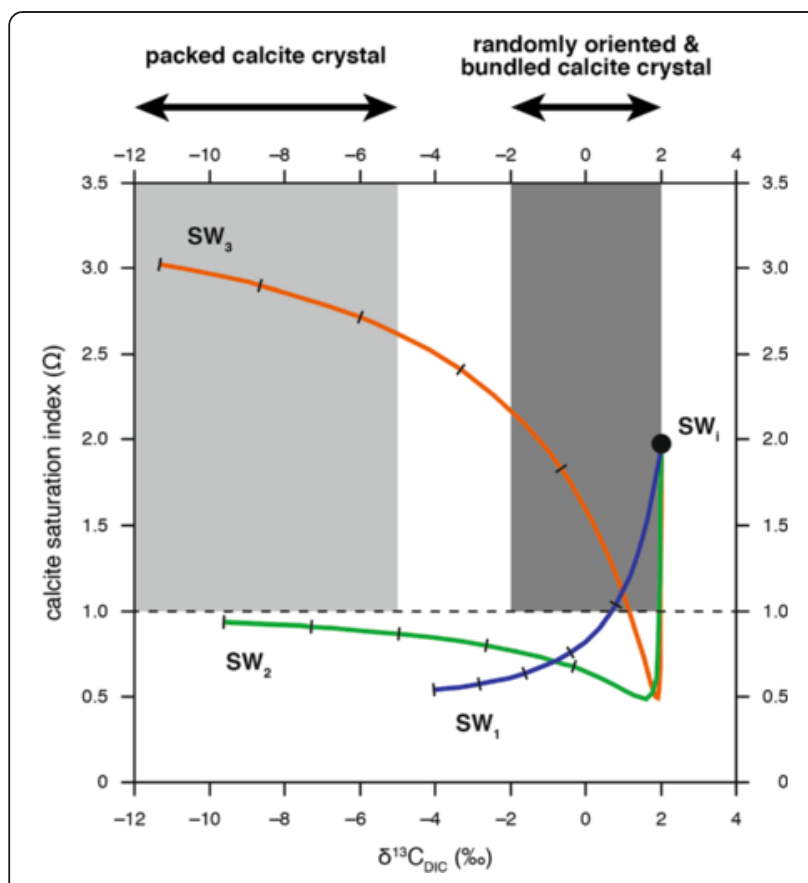

Fig. 7 Relationship between the $\delta^{13} C_{D I C}$ value and calcite saturation index $(\Omega)$ of the waters generated by mixing of the initial seawater $\left(S_{i} W_{i}\right)$ with the seawaters in which sulfate reduction occurred $\left(\mathrm{SW}_{1}, \mathrm{SW}_{2}, \mathrm{SW}_{3}\right)$ (Fig. 6). The mixing ratios of $\mathrm{SW}_{x}$ to $\mathrm{SW}_{i}(x=1,2,3)$ are 0 to 0.5 , and the tick marks on each curve represent the ratios; $0.1,0.2,0.3,0.4$, and 0.5 from right to left on each curve. The arrows represent the main ranges of $\delta^{13} C_{\text {carb }}$ values of randomly oriented and bundled calcites (right) and of packed calcites (left)

anoxic oceans, a gradient in carbonate saturation in the water column and sediments might have been small, thus promoting seafloor carbonate precipitation. The small $\Omega$ gradient in the Permian anoxic water column may also have contributed to the Chaotian carbonate precipitation near the sediment-water interface.

\section{Authigenic carbonate precipitation in the anoxic oceans}

Schrag et al. (2013) proposed that authigenic carbonate played a major role in the ancient carbon cycle. According to their model, authigenic carbonates are generally generated within the sediments by the decomposition of sedimentary organic matter via anaerobic respiration (such as sulfate and iron reduction) (e.g., Irwin et al. 1977; Meister et al. 2007; Dela Pierre et al. 2012). The anaerobic respiration in the sediments increases the alkalinity in the pore waters and remineralized organic carbon with low $\delta^{13} \mathrm{C}$ values is released, promoting the in situ carbonate precipitation. The waxing and waning of the global sink of ${ }^{13} \mathrm{C}$-depleted authigenic carbonate may have changed the $\delta^{13} C_{\text {DIC }}$ value in the ancient oceans without large fluctuations in atmospheric $\mathrm{O}_{2}$ and $\mathrm{CO}_{2}$ levels. Schrag et al. (2013) suggested two mechanisms for $\delta^{13} C_{\text {carb }}$ excursion in geologic records associated with authigenic carbonate precipitation. The change in $\delta^{13} C_{\text {DIC }}$ values due to a change in the size of the global authigenic carbonate sink would be recorded as a $\delta^{13} \mathrm{C}_{\text {carb }}$ excursion in geologic records ("type 1 excursion" according to Macdonald et al. 2013). Moreover, a local addition of ${ }^{13} \mathrm{C}$-depleted authigenic carbonate to normal marine carbonate would have declined the bulk $\delta^{13} \mathrm{C}_{\text {carb }}$ value in rock samples ("type 2 excursion" according to Macdonald et al. 2013).

Schrag et al. (2013) assumed that, in general, the $\delta^{13} \mathrm{C}_{\text {carb }}$ values of authigenic carbonates have been substantially lower than the $\delta^{13} C_{\text {DIC }}$ value of seawater in Earth's history. However, our results from Chaotian imply that the $\delta^{13} C_{c a r b}$ values of the authigenic carbonates in the oxic and anoxic oceans in the past may have been systematically different (Fig. 8). We propose that the depth of the redoxcline in the oceans has controlled the generation depth and $\delta^{13} C_{\text {carb }}$ values of the authigenic carbonate. In the oxic oceans, anaerobic respiration is largely restricted within the sediments because the redoxcline is below the seafloor. The authigenic carbonate precipitation due to increased alkalinity caused by respiration is also restricted within the sediments, as is observed in the modern oceans. The upward diffusive transport of remineralized carbon released from sedimentary organic matter and the downward diffusive transport of seawater DIC within the sediments are low, and vertical mixing of these two inorganic carbon pools is suppressed. As a result, the $\delta^{13} C_{\text {carb }}$ values of authigenic carbonate generated within the sediments are relatively low compared with that of the DIC in the water column. In marked contrast, the redoxcline in the anoxic oceans is generally within the water column and water-mass anaerobic respiration is enhanced. When the water-mass anaerobic respiration occurs, it is likely that remineralized carbon from suspended organic matter is released into the water column and mixed with the large oceanic DIC pool. The low $\delta^{13} \mathrm{C}$ values of remineralized organic carbon are likely diluted by the large DIC pool. In other words, the water-mass anaerobic respiration promotes the recycling of fixed organic carbon back to the large oceanic DIC pool. In the anoxic oceans, authigenic carbonate is mainly generated near the sediment-water interface rather than deep within the sediments (Higgins et al. 2009; Bergmann et al. 2013). As a result, the $\delta^{13} C_{\text {carb }}$ values of the authigenic carbonate precipitated near the sediment-water interface are close to the $\delta^{13} C_{\text {DIC }}$ value of seawater, although a minor amount of ${ }^{13} \mathrm{C}$-depleted carbonate may also have been generated within the sediments (Fig. 8).

Carbonates precipitated abundantly on the seafloor in the Archean (e.g., Sumner and Grotzinger 2000), while the occurrence of carbonate seafloor precipitates and cements declined during the Proterozoic (e.g., Grotzinger and James 2000), except for a brief revival in the late 


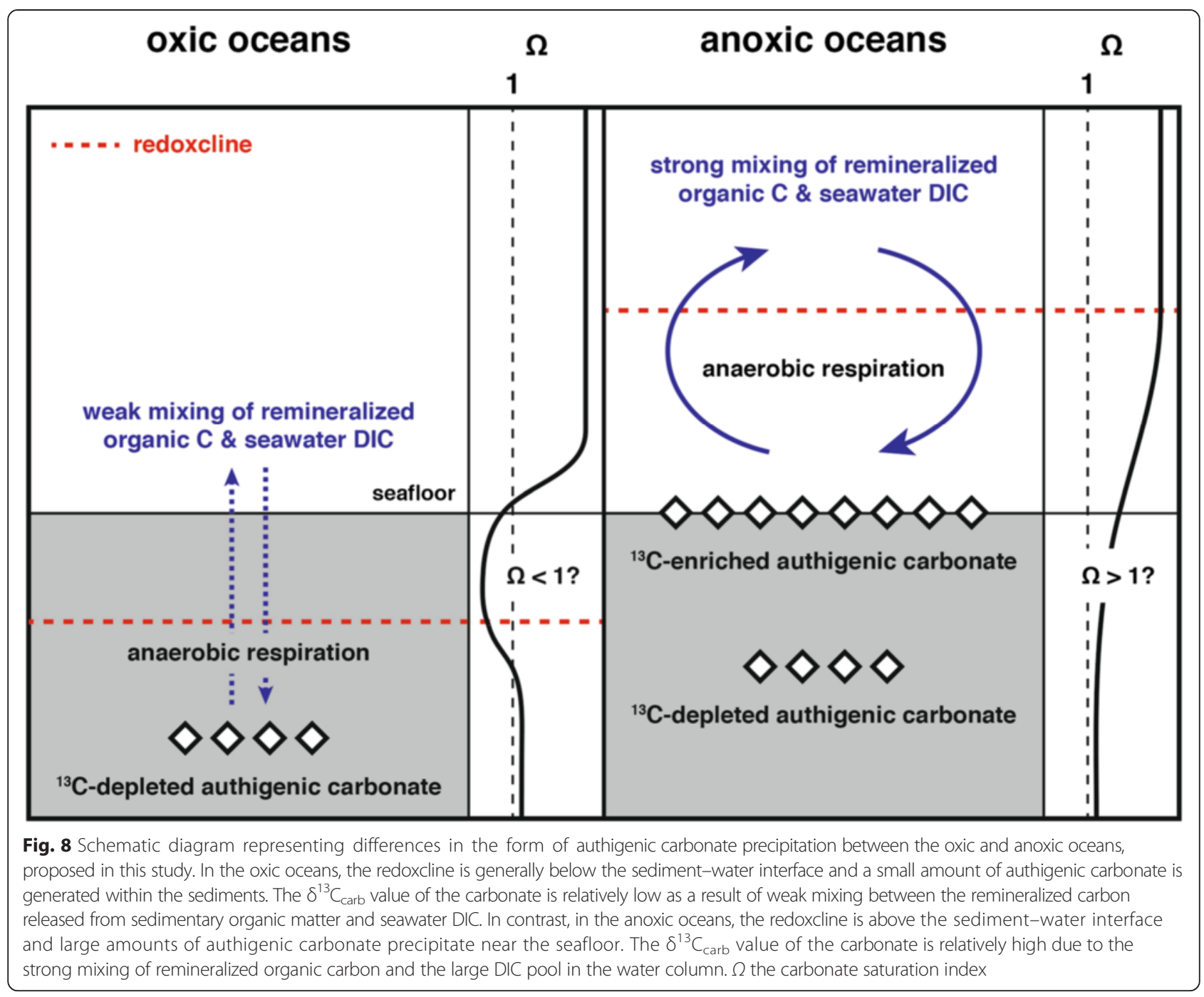

Neoproterozoic (e.g., Grotzinger and Knoll 1995; James et al. 2001; Pruss et al. 2008). In the Phanerozoic, carbonate seafloor precipitates are rare although they were widespread in the Paleozoic-Mesozoic transition interval where their precipitations are often associated with oceanic anoxia (e.g., Grotzinger and Knoll 1995; Woods et al. 1999, 2007, 2014; Heydari et al. 2003; Pruss et al. 2006; Baud et al. 2007). This secular trend in carbonate seafloor precipitation in Earth's history suggests that the carbonate precipitation has been generally related to oceanic anoxia (e.g., Grotzinger and Knoll 1995; Higgins et al. 2009). However, other factors may have also influenced the authigenic carbonate precipitation because oceanic anoxic events (OAEs) in the Phanerozoic were not always associated with the widespread occurrence of authigenic carbonates (e.g., Bergmann et al. 2013). Nonetheless, our results from Chaotian imply that when the authigenic carbonates precipitate near the sediment-water interface in anoxic oceans, their $\delta^{13} C_{\text {carb }}$ values are close to the $\delta^{13} C_{\text {DIC }}$ value of seawater. The systematic $\delta^{13} \mathrm{C}_{\text {carb }}$ differences in authigenic carbonate due to its generation depth have also been recognized in some Phanerozoic geologic records; the $\delta^{13} \mathrm{C}_{\text {carb }}$ values of Lower Triassic carbonate cements precipitated on the anoxic seafloor in California are relatively high $(+2.8$ to + $4.2 \%$ ) (Woods et al. 1999), whereas those of early diagenetic subseafloor carbonates around the Triassic-Jurassic boundary in British Columbia are relatively low (-7.6 to $-3.7 \%$ ) (Greene et al. 2012). Certain authigenic carbonates have been generated by anaerobic oxidation of methane in the ancient and modern oceans (e.g., Ritger et al. 1987; Michaelis et al. 2002; Allison et al. 2008; Bayon et al. 2013), although a detailed discussion of methanederived carbonates is beyond the scope of this study.

Our model for authigenic carbonate precipitation in the oxic and anoxic oceans does not exclude the significance of the authigenic carbonate sink over the course of Earth's history (Schrag et al. 2013). However, when the $\delta^{13} C_{\text {carb }}$ 
value of authigenic carbonate was relatively high and close to the $\delta^{13} C_{\text {DIC }}$ value in the oceans, the influence of a local addition of authigenic carbonate to normal marine carbonate on the bulk $\delta^{13} \mathrm{C}_{\text {carb }}$ value, causing a type 2 excursion in geologic records (Macdonald et al. 2013), would have been small. In the Precambrian anoxic oceans, diagenetic carbonates with relatively high $\delta^{13} \mathrm{C}_{\text {carb }}$ values may have been extensively generated within the methane zone in the sediments ( $\mathrm{Li}$ et al. 2015). Low sulfate and high DIC concentrations in the Precambrian oceans may also have suppressed ${ }^{13} \mathrm{C}$ depletion in authigenic carbonates (Bristow and Grotzinger 2013). Our model implies that, in the ancient anoxic oceans, the type 2 excursions may be less significant in geologic records than previously suggested (Schrag et al. 2013). In other words, the type 2 excursions might be limited to geologic records from oxic intervals in Earth's history because these excursions are caused by authigenic carbonates with substantially low $\delta^{13} \mathrm{C}_{\text {carb }}$ values. The existence of type 2 excursions, such as the Shuram anomaly in the Ediacaran (e.g., Grotzinger et al. 2011; Macdonald et al. 2013; Schrag et al. 2013), may therefore suggest oxic conditions in the oceans.

\section{Conclusions}

Authigenic carbonates are common in the anoxic interval of the upper Guadalupian Maokou Formation at Chaotian, Sichuan, China. Calcite crystals precipitated in situ mainly near the sediment-water interface, possibly associated with the water-mass anaerobic respiration. The relatively high $\delta^{13} C_{\text {carb }}$ values of the carbonates (largely about -1 $\%$ ) indicate that their main carbon source was seawater DIC. Our results suggest that the forms of authigenic carbonate precipitation in the oxic and anoxic oceans in the past may have been substantially different. In the anoxic oceans, authigenic carbonates likely precipitated near the seafloor with $\delta^{13} \mathrm{C}_{\text {carb }}$ values close to that of seawater DIC. The influence of authigenic carbonate on the bulk $\delta^{13} \mathrm{C}_{\text {carb }}$ values in geologic records from ancient anoxic oceans might have been overestimated in previous studies. A large negative $\delta^{13} C_{\text {carb }}$ excursion caused by the local addition of ${ }^{13} \mathrm{C}$-depleted authigenic carbonate to normal marine carbonate (type 2 excursion in Macdonald et al. 2013) may have been limited to oxic intervals in Earth's history and thus might be a useful indicator of the oxic conditions in the ancient oceans.

\section{Competing interests}

The authors declare that they have no competing interests.

\section{Authors' contributions}

MS designed the study. MS, YI, JXY, and ZSJ conducted the fieldwork and sampling. MS and YI conducted the petrological analyses. KS and MM conducted the XRD analyses. MS, YU, and NY conducted the isotopic analyses. MS and TS conducted the calculation analyses. MS, YU, YI, and TS wrote the paper. All authors read and approved the final manuscript.

\section{Authors' information}

MS is a project researcher at the Research and Development (R\&D) Center for Submarine Resources, Japan Agency for Marine-Earth Science and Technology (JAMSTEC). YU is an associate professor at the Department of Earth and Planetary Sciences and Earth-Life Science Institute, Tokyo Institute of Technology. YI is a professor at the Department of Earth Science and Astronomy, The University of Tokyo. TS is a scientist at the Laboratory of Ocean-Earth Life Evolution Research (OELE), Japan Agency for Marine-Earth Science and Technology (JAMSTEC). JXY is a professor at the Geology Institute, Chinese Academy of Geological Science. ZSJ is a research scientist at the Geology Institute, Chinese Academy of Geological Science. KS is an assistant professor at the Department of Chemistry, The University of Tokyo. MM is a professor, Department of Chemistry, The University of Tokyo. NY is a professor at the Department of Environmental Chemistry and Engineering and Earth-Life Science Institute, Tokyo Institute of Technology.

\section{Acknowledgements}

This study was supported by JSPS KAKENHI (16204040, 20224012, 26610159, 15H03740) and CGS (1212011120116, 1212011120143). YU is supported by the NEXT program of JSPS. Hodaka Kawahata and two anonymous reviewers provided constructive comments that improved the manuscript. Miyuki Tahata assisted with the isotopic analyses.

\section{Author details}

${ }^{1}$ Laboratory of Ocean-Earth Life Evolution Research (OELE), Japan Agency for Marine-Earth Science and Technology (JAMSTEC), 2-15 Natsushima-cho, Yokosuka 237-0061, Japan. ${ }^{2}$ Department of Earth and Planetary Sciences, Tokyo Institute of Technology, 2-12-1 Ookayama, Meguro, Tokyo 152-8551, Japan. ${ }^{3}$ Earth-Life Science Institute, Tokyo Institute of Technology, 2-12-1 Ookayama, Meguro, Tokyo 152-8551, Japan. ${ }^{4}$ Department of Earth Science and Astronomy, The University of Tokyo, 3-8-1 Komaba, Meguro, Tokyo 153-8902, Japan. Institute of Geology, Chinese Academy of Geological Science, Baiwanzhuang Road 26, Beijing 100037, China. ${ }^{6}$ Department of Chemistry, The University of Tokyo, 3-8-1 Komaba, Meguro, Tokyo 153-8902, Japan. 'Department of Environmental Chemistry and Engineering, Tokyo Institute of Technology, 4259 Nagatsuda, Midori, Yokohama 226-8502, Japan. ${ }^{8}$ Present address: Research and Development (R\&D) Center for Submarine Resources, Japan Agency for Marine-Earth Science and Technology (JAMSTEC), 2-15 Natsushima-cho, Yokosuka 237-0061, Japan.

Received: 15 December 2014 Accepted: 9 November 2015 Published online: 20 November 2015

\section{References}

Algeo TJ, Luo GM, Song HY, Lyons TW, Canfield DE. Reconstruction of secular variation in seawater sulfate concentrations. Biogeosciences. 2015;12:2131-51.

Allison PA, Hesselbo SP, Brett CE. Methane seeps on an early jurassic dysoxic seafloor. Palaeogeogr Palaeoclimatol Palaeoecol. 2008;270:230-8.

Arvidson RS, Mackenzie FT, Berner RA. The sensitivity of the Phanerozoic inorganic carbon system to the onset of pelagic sedimentation. Aquat Geochem. 2014;20:343-62.

Baud A, Richoz S, Pruss S. The lower Triassic anachronistic carbonate facies in space and time. Global Planet Change. 2007;55:81-9.

Bayon G, Dupré S, Ponzevera E, Etoubleau J, Chéron S, Pierre C, et al. Formation of carbonate chimneys in the Mediterranean Sea linked to deep-water oxygen depletion. Nat Geosci. 2013;6:755-60.

Bergmann KD, Grotzinger JP, Fischer WW. Biological influences on seafloor carbonate precipitation. Palaios. 2013;28:99-115.

Bethke CM. Geochemical and biogeochemical reaction modeling. 2nd ed. Cambridge: Cambridge University Press; 2008.

Bosak T, Corsetti FA, Newman DK. Micrometer-scale porosity as a biosignature in carbonate crusts. Geology. 2004;32:781-4.

Bristow TF, Grotzinger JP. Sulfate availability and the geological record of cold-seep deposits. Geology. 2013;41:811-4.

Dela Pierre F, Clari P, Bernardi E, Natalicchio M, Costa E, Cavagna S, et al. Messinian carbonate-rich beds of the Tertiary Piedmont Basin (NW Italy): microbially-mediated products straddling the onset of the salinity crisis. Palaeogeogr Palaeoclimatol Palaeoecol. 2012;344-345:78-93.

D'Hondt S. Consequences of the Cretaceous/Paleogene mass extinction for marine ecosystems. Annu Rev Ecol Evol Syst. 2005;36:295-317.

Greene SE, Bottjer DJ, Corsetti FA, Berelson WM, Zonneveld JP. A subseafloor carbonate factory across the Triassic-Jurassic transition. Geology. 2012;40:1043-6. 
Grotzinger JP, Knoll AH. Anomalous carbonate precipitates: is the Precambrian the key to the Permian? Palaios. 1995;10:578-96.

Grotzinger JP, James NP. Precambrian carbonates: evolution of understanding. In: Grotzinger JP, James NP, editors. Carbonate Sedimentation and Diagenesis in the Evolving Precambrian World, SEPM Special Publication, vol. 67. Tulsa: Oklahoma; 2000. p. 3-20.

Grotzinger JP, Fike DA, Fischer WW. Enigmatic origin of the largest-known carbon isotope excursion in Earth's history. Nat Geosci. 2011;4:285-92.

Hayes JM, Strauss $\mathrm{H}$, Kaufman AJ. The abundance of ${ }^{13} \mathrm{C}$ in marine organic matter and isotopic fractionation in the global biogeochemical cycle of carbon during the past 800 Ma. Chem Geol. 1999;161:103-25.

Heindel K, Richoz S, Birgel D, Brandner R, Klügel A, Krystyn L, et al. Biogeochemical formation of calyx-shaped carbonate crystal fans in the shallow subsurface of the Early Triassic seafloor. Gondwana Res. 2015;27:840-61.

Helgeson HC. Thermodynamics of hydrothermal systems at elevated temperatures and pressures. Am J Sci. 1969:267:729-804.

Helgeson HC, Kirkham DH. Theoretical prediction of the thermodynamic behavior of aqueous electrolytes at high pressures and temperatures; II, Debye-Huckel parameters for activity coefficients and relative partial molal properties. Am J Sci. 1974;274:1199-261.

Heydari E, Hassanzadeh J, Wade WJ, Ghazi AM. Permian-Triassic boundary interval in the Abadeh section of Iran with implications for mass extinction: part 1-sedimentology. Palaeogeogr Palaeoclimatol Palaeoecol. 2003;193:405-23.

Higgins JA, Fischer WW, Schrag DP. Oxygenation of the ocean and sediments: consequences for the seafloor carbonate factory. Earth Planet Sci Lett. 2009; 284:25-33.

Huber BT, Hodell DA, Hamilton CP. Middle-Late Cretaceous climate of the southern high latitudes: stable isotopic evidence for minimal equator-to-pole thermal gradients. GSA Bull. 1995;107:1164-91.

Irwin H, Curtis C, Coleman M. Isotopic evidence for source of diagenetic carbonates formed during burial of organic-rich sediments. Nature. 1977;269:209-13.

Isozaki Y, Yao JX, Matsuda T, Sakai H, Ji ZS, Shimizu N, et al. Stratigraphy of the Middle-Upper Permian and lowermost Triassic at Chaotian, Sichuan, China-record of Late Permian double mass extinction event. Proc Jpn Acad Ser B. 2004;80:10-6.

Isozaki Y, Yao JX, Ji ZS, Saitoh M, Kobayashi N, Sakai H. Rapid sea-level change in the Late Guadalupian (Permian) on the Tethyan side of South China: lithoand biostratigraphy of the Chaotian section in Sichuan. Proc Jpn Acad Ser B. 2008:80:344-53.

James NP, Narbonne GM, Kyser TK. Late Neoproterozoic cap carbonates: Mackenzie Mountains, northwestern Canada: precipitation and global glacial meltdown. Can J Earth Sci. 2001;38:1229-62.

Jin YG, Mei SL, Wang W, Wang XD, Shen SZ, Shang QH, et al. On the Lopingian series of the Permian System. Palaeoworld. 1998:9:1-18.

Kasting JF. Earth's early atmosphere. Science. 1993;259:920-6.

Kennett JP, Stott LD. Abrupt deep-sea warming, palaeoceanographic changes and benthic extinctions at the end of the Palaeocene. Nature. 1991:353:225-9.

Knauth LP, Kennedy MJ. The late Precambrian greening of the Earth. Nature. 2009:460:728-32

Kroopnick PM. The distribution of $13 \mathrm{C}$ of $\Sigma \mathrm{CO} 2$ in the world oceans. Deep-Sea Res. 1985:32:57-84.

Lam P, Lavik G, Jensen MM, van de Vossenberg J, Schmid M, Woebken D, et al. Revising the nitrogen cycle in the Peruvian oxygen minimum zone. Proc Nat Acad Sci U S A. 2009;106:4752-7.

Li C, Planavsky NJ, Love GD, Reinhard CT, Hardisty D, Feng LJ, et al. Marine redox conditions in the middle Proterozoic ocean and isotopic constraints on authigenic carbonate formation: insights from the Chuanlinggou Formation, Yanshan Basin, North China. Geochim Cosmochim Acta. 2015;150:90-105.

Macdonald FA, Strauss JV, Sperling EA, Halverson GP, Narbonne GM, Johnston DT, et al. The stratigraphic relationship between the Shuram carbon isotope excursion, the oxygenation of Neoproterozoic oceans, and the first appearance of the Ediacara biota and bilaterian trace fossils in northwestern Canada. Chem Geol. 2013;362:250-72.

Meister P, McKenzie JA, Vasconcelos C, Bernasconi S, Frank M, Gutjahr M, et al. Dolomite formation in the dynamic deep biosphere: results from the Peru Margin. Sedimentology. 2007:54:1007-31.

Meister P. Two opposing effects of sulfate reduction on carbonate precipitation in normal marine, hypersaline, and alkaline environments Geology. 2013;41:499-502.
Michaelis W, Seifert R, Nauhaus K, Treude T, Thiel V, Blumenberg M, et al. Microbial reefs in the Black Sea fueled by anaerobic oxidation of methane. Science. 2002;297:1013-5.

Naehr TH, Eichhubl P, Orphan VJ, Hovland M, Paull CK, Ussler W, et al. Authigenic carbonate formation at hydrocarbon seeps in continental margin sediments: a comparative study. Deep-Sea Res II. 2007;54:1268-91.

Porter SM. Seawater chemistry and early carbonate biomineralization. Science. 2007;316:1302.

Pruss SB, Bottjer DJ, Corsetti FA, Baud A. A global marine sedimentary response to the end-Permian mass extinction: examples from southern Turkey and the western United States. Earth-Sci Rev. 2006;78:193-206.

Pruss SB, Corsetti FA, Fischer WW. Seafloor-precipitated carbonate fans in the Neoproterozoic Rainstorm Member, Johnnie Formation, Death Valley Region, USA. Sed Geol. 2008;207:34-40.

Revesz KM, Landwehr JM. $\delta^{13} \mathrm{C}$ and $\delta^{18} \mathrm{O}$ isotopic composition of $\mathrm{CaCO}_{3}$ measured by continuous flow isotope ratio mass spectrometry: statistical evaluation and verification by application to Devils Hole core $\mathrm{DH}-11$ calcite. Rapid Commun Mass Spectrom. 2002;16:2102-14.

Ridgwell A. A Mid Mesozoic Revolution in the regulation of ocean chemistry. Mar Geol. 2005;217:339-57.

Ridgwell A, Zeebe RE. The role of the global carbonate cycle in the regulation and evolution of the Earth system. Earth Planet Sci Lett. 2005;234:299-315.

Ritger S, Carson B, Suess E. Methane-derived authigenic carbonates formed by subduction-induced pore-water expulsion along the Oregon/Washington margin. GSA Bull. 1987;98:147-56.

Saitoh M, Isozaki Y, Yao JX, Ji ZS, Ueno Y, Yoshida N. The appearance of an oxygen-depleted condition on the Capitanian disphotic slope/basin in South China: Middle-Upper Permian stratigraphy at Chaotian in northern Sichuan. Global Planet Change. 2013a;105:180-92.

Saitoh M, Isozaki Y, Ueno Y, Yoshida N, Yao JX, Ji ZS. Middle-Upper Permian carbon isotope stratigraphy at Chaotian, South China: pre-extinction multiple upwelling of oxygen-depleted water onto continental shelf. J Asian Earth Sci. 2013b;67-68:51-62.

Saitoh M, Ueno Y, Isozaki Y, Nishizawa M, Shozugawa K, Kawamura T, et al. Isotopic evidence for water-column denitrification and sulfate reduction at the endGuadalupian (Middle Permian). Global Planet Change. 2014a;123:110-20.

Saitoh M, Ueno Y, Nishizawa M, Isozaki Y, Takai K, Yao JX, et al. Nitrogen isotope chemostratigraphy across the Permian-Triassic boundary at Chaotian, Sichuan, South China. J Asian Earth Sci. 2014b;93:113-28.

Sandberg PA. An oscillating trend in Phanerozoic non-skeletal carbonate mineralogy. Nature. 1983;305:19-22.

Schrag DP, Higgins JA, Macdonald FA, Johnston DT. Authigenic carbonate and the history of the global carbon cycle. Science. 2013;339:540-3.

Scotese CR, Langford RP. Pangea and the Paleogeography of the Permian. In: Scholle A, Peryt TM, Ulmer-Scholle DA, editors. The Permian of Northern Pangea, 1. Berlin: Springer; 1995.

Shackleton NJ, Hall MA. Carbon isotope data from Leg 74 sediments. Initial Reports Deep Sea Drill Project. 1984;74:613-9.

Shields G, Veizer J. Precambrian marine carbonate isotope database: Version 1.1. Geochem Geophys Geosyst 2002. doi:10.1029/2001GC000266

Stanley SM, Hardie LA. Secular oscillations in the carbonate mineralogy of reefbuilding and sediment-producing organisms driven by tectonically forced shifts in seawater chemistry. Palaeogeogr Palaeoclimatol Palaeoecol. 1998;144:3-19.

Sumner DY, Grotzinger JP. Late Archean aragonite precipitation: petrography, facies associations, and environmental significance. In: Grotzinger JP, James NP, editors. Carbonate Sedimentation and Diagenesis in the Evolving Precambrian World, SEPM Special Publication, vol. 67. Tulsa: Oklahoma; 2000. p. 123-44.

Sun $\mathrm{XL}$, Turchyn AV. Significant contribution of authigenic carbonate to marine carbon burial. Nat Geosci. 2014;7:201-4

Van der Kooij B, Immenhauser A, Steuber T, Bahamonde JR, Meríno-Tomé O. Controlling factors of volumetrically important marine carbonate cementation in deep slope settings. Sedimentology. 2010;57:1491-525.

Walker JCG, Hays PB, Kasting JF. A negative feedback mechanism for the long-term stabilization of Earth's surface temperature. J Geophys Res. 1981;86:9776-82.

Wang Y, Jin YG. Permian palaeogeographic evolution of the Jiangnan Basin, South China. Palaeogeogr Palaeoclimatol Palaeoecol. 2000;160:35-44.

Whiticar MJ. Carbon and hydrogen isotope systematics of bacterial formation and oxidation of methane. Chem Geol. 1999;161:291-314.

Woods AD, Bottjer DJ, Mutti M, Morrison J. Lower Triassic large sea-floor carbonate cements: their origin and a mechanism for the prolonged biotic recovery from the end-Permian mass extinction. Geology. 1999;27:645-8. 
Woods AD, Bottjer DJ, Corsetti FA. Calcium carbonate precipitates from the outer shelf to slope facies of the Lower Triassic (Smithian-Spathian) Union Wash Formation, California, USA: sedimentary and palaeobiologic significance. Palaeogeogr Palaeoclimatol Palaeoecol. 2007;252:281-90.

Woods AD. Assessing Early Triassic paleoceanographic conditions via unusual sedimentary fabrics and features. Earth-Sci Rev. 2014;137:6-18.

Zhao JK, Sheng JZ, Yao ZQ, Liang XL, Chen CZ, Rui L, et al. The Changhsingian and Permian-Triassic boundary of South China. Bull Nanjing Inst Geol Paleontol Acad Sinica. 1981;2:1-112.

Submit your manuscript to a SpringerOpen ${ }^{\odot}$ journal and benefit from:

- Convenient online submission

- Rigorous peer review

- Immediate publication on acceptance

- Open access: articles freely available online

- High visibility within the field

- Retaining the copyright to your article

Submit your next manuscript at $\gg$ springeropen.com 